\title{
The Right to Public Participation in Resources AND ENVIRONMENTAL DECISION-MAKING IN ALBERTA
}

\author{
SHAUN FLUKER*
}

This article examines the right to public participation in resources and environmental decisionmaking in Alberta. The only reasonable conclusion from the analysis in the paper is that there is currently no legal right to public participation in resources and environmental project decision-making in Alberta. Project decision-makers have no obligation to hear organized public interest groups or members of the public at large who are unable to demonstrate how a project may personally affect them. The public interest character of resource development decisions has thus far had no identifiable impact on the consideration of participatory rights by Alberta courts. Resources and environmental project decision-making is thus not necessarily subject to public scrutiny and it becomes more difficult to hold officials exercising public power over resource development legally accountable for their actions. The role of public participation as an accepted means to influence the exercise of state power over matters concerning the public interest deserves more critical and focused attention from Alberta courts.
Cet article porte sur le droit à la participation publique dans les décisions sur les ressources et l'environnement en Alberta. La seule conclusion raisonnable de cet article est le fait qu'il n'existe actuellement aucun droit juridique à la participation publique dans les décisions sur les ressources et les projets environnementaux dans la province. Les décideurs de ces projets n'ont aucune obligation d'entendre les groupes organisés de défense de l'intérêt public ou les membres du grand public qui ne sont pas en mesure de démontrer comment un projet les touchera personnellement. L'intérêt public des décisions sur l'exploitation des ressources n'a jusqu'à présent pas eu d'impact identifiable sur la considération de droits participatifs dans les tribunaux albertains. Les décisions sur les ressources et les projets environnementaux ne font donc pas nécessairement l'objet de l'examen du public. Il est donc plus difficile de tenir les fonctionnaires des autorités publiques chargées de l'exploitation des ressources juridiquement responsables de leurs actions. Le rôle de la participation publique en tant que moyen accepté d'influencer l'exercice du pouvoir de l'État sur les questions touchant l'intérêt public mérite une attention plus critique et ciblée de la part des tribunaux albertains.

\section{TABLE OF CONTENTS}

I. INTRODUCTION . . . . . . . . . . . . . . . . . . . . . . . . . . . . . . 568

II. Some Context on Public PARTICIPATION . . . . . . . . . . . . . . 570

III. Public Participation in Resource Project Reviews . . . . . . . . . 576

A. Public Participation at Alberta EnVironment

AND SustainABLE RESOURCE DEVELOPMENT AND THE

Alberta EnVIRONMENTAL APPEALs BoARd . . . . . . . . 578

B. Public Participation at the Alberta

ENERGY REGULATOR AND ITS PREDECESSOR

ENERGY RESOURCES CONSERVATION BOARD . . . . . . . . . . 583

C. Public Participation AT THE

NATURAL RESOURCES CONSERVATION BOARD . . . . . . . . . . . . . 590

Associate Professor of Law, University of Calgary. The author would like to thank several anonymous reviewers for their instructive feedback on a previous draft. This investigation began as an examination into public participation at the Energy Resources Conservation Board and a presentation to attendees of the 2010 conference on Public Participation in Alberta's Energy and Natural Resources Development hosted by the Canadian Institute of Resources Law. The author expresses gratitude to Christine Laing and Monique Passelac-Ross for providing research assistance and feedback during the early stages of this research project. 


\section{Concluding Thoughts On Public Participation}

IN REsource Project REVIEWS . . . . . . . . . . . . . . . . . . . . . . . . . 594

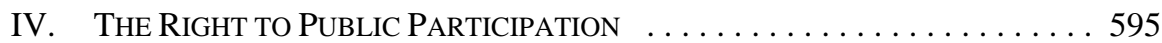

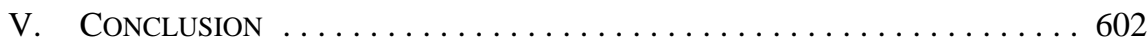

\section{INTRODUCTION}

Resources and environmental decision-making is a matter of public governance in Alberta. The provincial government, and to a lesser extent the federal government, regulate this area with a large volume of primary and subordinate legislation. These statutory rules provide a range of decision-makers with authority to make resource development decisions. These executive and administrative decisions cover the full spectrum of policies, allocations, dispositions, approvals, and reviews that govern resource exploration and development from upstream production to downstream consumption and export. Implicit in this grant of power is that it be exercised to further the public interest.

Resource development has generated economic fruits across the Albertan landscape. If the public interest were measurable in dollars alone, it would seem unfathomable that organized opposition to resource development exists here. But it does. Collective opposition to the resource industry in Alberta may have its beginnings near Pincher Creek with people who complained of health disorders during the 1960s, which they alleged were caused by exposure to sour gas being produced in nearby gas plants. ${ }^{1}$ Since that time, opposition to resource development in Alberta has grown in step with the industry's expanding footprint in the province. Resource development projects today are of such a magnitude that they almost always conflict with environmental and other interests. These conflicts have led many to participate in the executive and administrative decisions that govern resource development in Alberta.

Looking back now, the first wave of collective opposition to resource development had what seems like easy access to decision-makers. Individuals or groups who wanted to voice their opinion on the merits of a resource development policy or a particular project generally had the opportunity to do so. The public interest was open to question, environmental protection was in vogue, and participation in resources and environmental decision-making during the 1970s and 1980s was generally not an issue. ${ }^{2}$ It is difficult to pinpoint exactly when the door to public participation in resources and environmental decision-making began to close in Alberta. The signs point to a decision by the Alberta government to approve a controversial pulp mill in late 1990 and the subsequent refusal to hear public opposition on its socio-ecological effects as the beginning of the demise for public participation in

1 There is surprisingly little commentary on this point. For some discussion see Andrew Nikiforuk, Saboteurs: Wiebo Ludwig's War Against Big Oil (Toronto: Macfarlane Walter \& Ross, 2001) at 20-30. PS Elder notes the Alberta government was dismissive of these concerns, and that litigation between residents and energy companies operating in the region was settled out of court: see PS Elder, "The Participatory Environment in Alberta” (1974) 12:3 Alta L Rev 403 at 425.

2 This statement is a bit sweeping, and it may be that some faced barriers to participation. My statement here is based on the literature of the time. For some commentary see PA Rowbotham, "The Growth of Public Participation in Decisions of the Energy Resources Conservation Board” (1994) 32:3 Alta L Rev 468. 
resources and environmental decision-making in Alberta. ${ }^{3}$ Stricter views from decisionmakers on the entitlement to participate are certainly apparent by the mid-1990s, giving rise to the issue of a right to participate in resources and environmental decision-making explored here.

This article describes the author's investigation into the right to public participation in resources and environmental decision-making in Alberta. This is a different matter from asking who may participate. Those with authority to make decisions in the public interest arguably have the discretionary power to invite a wide range of participants into resources and environmental decision-making processes. But to whom do these decision-makers owe a legal obligation to hear? The fundamental question asked here is whether a decision-maker responsible for furthering the public interest in resource development is obligated to hear from the public.

Resources and environmental decision-making occurs at one of several levels in public governance, and therefore any assessment of public participation must specify which level is being examined. Public participation often features in regional land-use planning by governments and it may also occur at the more specific stages of mineral rights disposition or project review. Generally speaking, a person seeking to participate in resources and environmental decision-making in Alberta must do so before a resource project decisionmaker. Accordingly, this article focuses on the right to participate in a resource project review.

The doctrinal analysis in Parts III and IV shows there is currently no legal right to public participation in resources and environmental project decision-making in Alberta. Relevant decision-makers interpret their legal obligation as requiring them to hear only those persons who can demonstrate they may be personally affected by a decision concerning resource development and its environmental effects. All others only participate at the discretion of the decision-maker, which is not a right to participate but merely an invitation. Alberta courts have endorsed this interpretation.

Part II of the article gives an overview of the political and legal context for public participation. The value we ascribe to public participation is connected to our view on the proper relationship between the state and its citizens, and our thoughts on who ought to determine the public interest. Thus debates over the appropriateness of public participation often come across as two ships passing in the night. One side of the debate has little regard for public input in resources and environmental decision-making, while the other side of the debate views public input as an essential component of any decision that is purported to be in furtherance of the public interest. In light of these competing visions on public participation, the importance of the debate for public governance, and the public interest character of resource development decisions, it is surprising and somewhat disappointing to observe in Part IV that as resource project decision-makers have increasingly narrowed their

Mary Richardson, Joan Sherman, and Michael Gismondi were involved in the controversy over the Alpac mill and studied how public participation was curtailed in the proceedings. They astutely predicted these proceedings would lead to the demise of public participation in Joan Sherman, Michael Gismondi \& Mary Richardson, "Not Directly Affected: Using the Law to Close the Door on Environmentalists" (1996) 31:1 J Canadian Studies 102. 
view on the scope of persons they are obligated to hear in a project review. Alberta courts have not given more critical and focused attention to the issue of public participation in resources and environmental project decision-making.

\section{Some Context on Public Participation}

Public participation is generally thought to have become a component of resources and environmental decision-making in the 1960s and the subject has since received significant attention from policy-makers and scholars. ${ }^{4}$ A precise definition of public participation is elusive, ${ }^{5}$ but nonetheless the subject is essentially concerned with persons having an opportunity to influence the exercise of decision-making power. In cases where this opportunity is contested, the primary issues are determining who has the right to participate in the decision-making process and what entitlements accompany such participation. ${ }^{6}$ In relation to a resource development project review, these questions seem most contentious when persons without a property or economic interest at stake in the process seek to participate.

Barton explores the values ascribed to public participation, and he identifies how these values are influenced by theories of the state and its relationship with citizens. ${ }^{7}$ I will summarize four of such theories covered by Barton that are relevant to the doctrinal analysis of public participation in resources and environmental decision-making conducted in Parts III and IV of this article. This summary is provided here simply for context, and the theories below are not set out to support a normative claim on the current state of public participation in Alberta concerning resources and environmental decision-making. The absence of public participation and the narrow category of persons with the right to participate in the exercise of state power over resource development most certainly have significant implications for

Barry Barton provides a comprehensive review of the literature concerning public participation in resources and environmental decision-making in Barry Barton, "Underlying Concepts and Theoretical Issues in Public Participation in Resources Development” in Donald N Zillman, Alastair R Lucas \& George (Rock) Pring, eds, Human Rights in Natural Resource Development: Public Participation in the Sustainable Development of Mining and Energy Resources (Oxford: Oxford University Press, 2002) 77. Barton covers a significant volume of literature and no attempt is made here to replicate his work. See generally Alastair R Lucas, "Legal Foundations for Public Participation in Environmental Decisionmaking” (1976) 16:1 Natural Resources J 73; Raj Anand \& Ian G Scott, "Financing Public Participation in Environmental Decision Making” (1982) 60:1 Can Bar Rev 81; Nigel Bankes \& J Owen Saunders, eds, Public Disposition of Natural Resources: Essays from the First Banff Conference on Natural Resources Law (Calgary: Canadian Institute of Resources Law, 1984); Steven A Kennett, ed, Law and Process in Environmental Management: Essays from the Sixth CIRL Conference on Natural Resources Law (Calgary: Canadian Institute of Resources Law, 1993); Neil J Brennan, "Private Rights and Public Concerns: The 'Public Interest' in Alberta’s Environmental Management Regime” (1997) 7 J Envtl L \& Practice 243; Benjamin J Richardson \& Jona Razzaque, "Public Participation in Environmental Decision-making” in Benjamin J Richardson \& Stepan Wood, eds, Environmental Law for Sustainability: A Reader (Oxford: Hart, 2006) 165; Rebeca Macias, "Public Participation in Energy and Natural Resources Development: A Theory and Criteria for Evaluation” (2010) Paper 34 Canadian Institute of Resources Lw, Occasional Papers.

$5 \quad$ Barton, ibid at 78 .

$6 \quad$ It is difficult to separate questions on the right to participate, and certainly the ability to exercise any opportunity to participate, from the entitlements that accompany that participation. Most notably whether there is funding provided to cover or offset the costs incurred to participate. As well participation comes in various shapes and sizes. It may involve as little as notification or access to information from the decision-maker. On the other extreme, it may allow for oral submissions, cross-examination of other participants, and legal argument. While cognizant of the relevance of these issues to the question of public participation, this article only looks at the bare right to participate in the decision-making process and engages on these entitlement questions only in passing as the context demands. See generally Barton, supra note 4 at 84-99. 
the relationship between Albertans and their government. However, a thorough assessment of these implications is left for interested readers to pursue on their own.

Rational elitism views resource development and the assessment of its socio-ecological impacts as a complex matter best resolved by scientists and other experts. This view has little regard for participation by lay people because they lack specialized expertise necessary to contribute to the process. Public participation is chastised for adding unnecessary delay and cost to the project review process. This view seems to underlie the rules governing participation in the environmental impact assessment of a resource development project in Alberta. The review of applicable legislation in Part III illustrates there is no opportunity for public input during the assessment process itself. The assessment is completed by a project proponent to the satisfaction of state officials in the absence of public scrutiny.

Liberal democracy is more accepting of public participation as a means to hold state officials accountable to the governed in their exercise of power over the disposition of public lands and resources. This view also believes public participation helps to legitimize the decision in question. As a liberal theory however, political and legal rights are contingent on owning property. And thus this view generally limits participation in state decisions to those persons whose individual property rights may be adversely impacted by the outcome. The analysis in Parts III and IV demonstrates the strong influence of liberal democracy in how the right to participate in Alberta is administered by resources and environmental decisionmakers and delineated by the judiciary. Common to each applicable statute is a provision that provides a right of participation to, or alternatively an obligation to hear, those persons who can demonstrate they may be directly affected by the resource development project in question. The various decision-makers and the judiciary alike have applied and interpreted these provisions to mean the right to participate is only held by individuals who can demonstrate the project may have an adverse affect on them personally.

Pluralism expands the reach of public participation beyond simply those whose individual rights are adversely affected to all persons with a demonstrated interest in the outcome. This view seems to underlie early descriptions of public participation in Canada. Andrew Roman was a frequent contributor to the literature on this subject at the time and described an "opendoor policy” of state agencies:

[I]n Canada there are very few reported cases of a regulatory tribunal denying standing to anyone. The prevailing federal and provincial regulatory practice is to allow anyone who wishes to intervene to do so, without any formal consideration of standing.... Notwithstanding their virtually open-door policy, Canadian tribunals have not complained about the number of parties appearing before them. ${ }^{8}$

The federal environmental assessment process as it was until 2012 under the now-repealed Canadian Environmental Assessment Act ${ }^{9}$ was an illustration of pluralism. Any person with an interest in the outcome of an environmental assessment was entitled to participate in the decision-making process, and federal authorities were obligated to include public 
participation, understood in its broadest sense to include all interested persons, in comprehensive studies and panel reviews conducted under the legislation. ${ }^{10}$ The Canadian Environmental Assessment Act, $2012^{11}$ now restricts participation in a federal environmental assessment to those who are directly affected by the project in question. ${ }^{12}$ Whether this amendment reflects a shift to the views on public participation espoused in rational elitism or liberal democracy remains to be seen, but it is a significant departure from pluralism nonetheless. ${ }^{13}$

Deliberative democracy takes public participation beyond the shackles of liberalism by rejecting the presumption of decision-making authority held exclusively by state officials. ${ }^{14}$ Public participation becomes not just a means of legitimizing state decisions, holding officials to account or ensuring all interested persons provide input, but rather participation is the vehicle by which decision-making power is distributed equally to all those affected to produce a consensus-based decision. This view is critical of structure or discourse which favours certain participants over others, and thereby prevents the possibility of true consensus in decision-making. For example, it questions the effectiveness of public participation in a process where such participation only occurs after prior decisions have been made which more or less ensures the outcome will be to the advantage of some participants over others. An application of this theory to the Alberta governance framework would be critical of the fact that the disposition of mineral rights to explore and develop resources on Crown lands precedes the opportunity for public input on the development at the project review stage wherein the rights holder seeks regulatory approval to exploit or recover the resource.

The right to public participation in resources and environmental decision-making is referenced and implemented by international law. The 1992 United Nations Rio Declaration expressly endorses public participation in environmental issues. ${ }^{15}$ Canada is not a signatory to the most relevant international law on public participation in resources and environmental decision-making which is the Aarhus Convention enacted by the United Nations Economic Commission for Europe. ${ }^{16}$ Article 6 of the Aarhus Convention calls for signatory countries to establish a legal right to public participation in state decision-making concerning specified resource development projects, manufacturing, and other industrial processing activities. This right to participate extends to any person with an interest in the decision, and expressly

Ibid, ss 21.2, 34(b).

SC 2012, с 19, s 52

Ibid, ss 2(2), 43(1). For some discussion of these changes to federal environmental assessment see Meinhard Doelle, “CEAA 2012: The End of Federal EA As We Know It?” (2012) 24:1 J Envt Law \& Practice 1.

13 Early environmental assessments conducted under the Canadian Environmental Assessment Act, 2012 suggest the new legislation may not necessarily result in more limited public participation, as these panels have interpreted the new "directly affected" phrase generously to include a wide range of persons. For some commentary on this point see Martin Olszynski, "New Prosperity Mine Panel Report: A 'Liberal and Generous,' 'Complex,' and Rigorous Interpretation of CEAA 2012” (8 November 2013), Ablawg.ca (blog), online: <ablawg.ca/2013/11/08/new-prosperity-mine-panel-report-a-liberal-andgenerous-complex-and-rigorous-interpretation-of-ceaa-2012/>.

14 See e.g. Macias, supra note 4. Macias explores the application of deliberative democracy to resources and environmental decision-making.

Report of the United Nations Conference on Environment and Development, Res 1, GA, UN Doc A/Conf.151/26 (1992) [Rio Declaration].

Convention on Access to Information, Public Participation in Decision-Making and Access to Justice in Environmental Matters, 25 June 1998, 2161 UNTS 447 (entered into force 30 October 2001) [Aarhus Convention]. For some commentary on the Aarhus Convention see Macias, supra note 4 at 41-45. 
deems public interest environmental organizations conducting policy work in the relevant field as having an affected interest. The analysis in Parts III and IV demonstrates this is clearly not the case in Alberta.

In relation to the law of Alberta specifically, the right to participate in resources and environmental decision-making is governed primarily by legislation and these statutory provisions along with their application by decision-makers are examined in Part III. As well, Alberta courts have developed a body of jurisprudence interpreting these provisions. These judicial decisions are examined in Part IV. The right to participate is thus predominately viewed as a statutory interpretation problem. However, two common law doctrines also have some association to the question of participatory rights. One is the doctrine of standing which consists of rules generally concerned with keeping "mere busybodies" from commencing legal proceedings or ensuring that a decision-maker only hears from those with a stake in the outcome. The other is the doctrine of procedural fairness, which holds that a person has a right to be heard by a public authority before it makes a decision that may affect that person's interests. The statutory character of legal rules governing the right to participate issue in Alberta seems to overshadow the influence of these doctrines in the jurisprudence. But nonetheless their influence is apparent in decisions, in particular that of the law on standing, and therefore some understanding of the common law in these subjects is necessary to grasp fully how the right to participate is administered in resources and environmental decisionmaking.

The law of standing concerns the entitlement of a claimant to commence legal proceedings. A decision-maker will typically convene a standing deliberation where it is alleged the applicant or claimant does not have a sufficient interest to initiate legal proceedings. In a dispute over private rights there is usually no issue of standing because each party has an obvious interest in the proceedings. For example, a dispute between contracting parties over the interpretation of terms in their negotiated bargain or a landowner asserting another person is unreasonably interfering with the use or enjoyment of his or her land each involves direct, personal interests on both sides. Similarly in a regulatory proceeding, the applicant seeking an approval or licence has an obvious interest in the proceedings. The standing issue is more acute in proceedings commenced in the name of asserting a public right or interest, where the claimant does not have an obvious interest as it is understood in private law.

The common law standing rule applicable in proceedings commenced to assert a public right or interest is the same rule that is applied in cases of public nuisance. ${ }^{17}$ The tort seeks to abate or compensate for an act that unreasonably interferes with a public right or interest in matters such as health, safety, morality, or access to communal resources. ${ }^{18}$ Public nuisance is considered a crime against the community, and on this basis the Crown has presumptive standing to initiate the claim. ${ }^{19}$ In its 2004 British Columbia v. Canadian Forest

17 See generally Ontario Law Reform Commission, Report on the Law of Standing (Ontario Ministry of the Attorney General, 1989) at ch 2.

18 Lewis N Klar, Tort Law, 4th ed (Toronto: Thomson Carswell, 2008) at 721-23. For a recent statement from the Supreme Court of Canada on public nuisance see Ryan v Victoria (City), [1999] 1 SCR 201 at para 52.

19 Klar, ibid. 
Products Ltd. decision the Supreme Court of Canada confirmed the authority of the Crown to initiate legal proceedings on behalf of the public to abate or compensate for activity that adversely interferes with the use and enjoyment of public resources. ${ }^{20}$ Generally speaking in relation to a claim asserting a public right or interest, someone other than the Crown can only obtain standing by demonstrating they have suffered damage which is different from that suffered by the public generally. ${ }^{21}$

In a quartet of decisions between 1975 and 1986 the Supreme Court of Canada developed a public interest exception to this traditional standing rule, and the Court revisited and affirmed the exception in a more recent 2012 decision. ${ }^{22}$ The public interest exception allows a claimant whose rights or interests are too remote or otherwise not directly affected by the impugned act, but who otherwise has a genuine interest in the matter, to commence legal proceedings that challenge the constitutionality of legislation or seek judicial review concerning the implementation of legislation. The Supreme Court of Canada has emphasized that public interest standing serves to enable members of the public to challenge the legality of state action where the issue in question transcends the interests of those most directly affected or the state action would otherwise be immune from legal scrutiny. ${ }^{23}$ While public interest standing alleviates some of the traditional limitations inherent in standing, it is an exception to the rule and is available only in the discretion of the Court and not as a matter of right. ${ }^{24}$

The doctrine of standing is generally about limiting access to legal process and ensuring only those claimants with a direct, personal interest in the outcome can initiate proceedings. The reasons for the doctrine, at least traditionally, are to preserve scarce judicial resources by screening out "mere busybodies" and to ensure the parties in legal proceedings are true adversaries and thus provide the court with contending arguments. A proceeding to assert the public interest must generally be initiated by the Crown. The underlying presumption here is that determining the public interest is the domain of the state. In all cases the onus to demonstrate standing is squarely on the person whose right to participate is in question. One might suggest the doctrine of standing is the antithesis to public participation in its pluralist

[2004] 2 SCR 74 at para 66. This decision involved a claim by the Crown for environmental damages resulting from a forest fire caused by negligent burning by Canfor in its logging operations. For commentary on this decision in the context of a public nuisance claim for environmental damages see Jerry V DeMarco, Marcia Valiante \& Marie-Ann Bowden, "Opening the Door for Common Law Environmental Protection in Canada: The Decision in British Columbia v. Canadian Forest Products Ltd.” (2005) 15:2 J Envtl L \& Practice 233.

$21 \quad$ Klar, supra note 18.

22 The quartet of decisions are: Thorson v Attorney General of Canada, [1975] 1 SCR 138; Nova Scotia Board of Censors v McNeil, [1976] 2 SCR 265; Minister of Justice of Canada v Borowski, [1981] 2 SCR 575; Finlay v Canada (Minister of Finance), [1986] 2 SCR 607. The more recent decision is Canada (Attorney General) v Downtown Eastside Sex Workers United Against Violence Society, 2012 SCC 45, [2012] 2 SCR 524 [Downtown Eastside Sex Workers]. To establish public interest standing the claimant must demonstrate: (1) there is a serious and justiciable issue; (2) the claimant is directly affected by the issue or has a genuine interest therein; and (3) the claim is a reasonable and effective manner in which the issue may be brought before the courts. These three matters are not to be considered independently, but rather they should be considered together and applied in light of the overall purpose for public interest standing in seeking to uphold the principle of legality in government action. The first application of public interest standing in Alberta came in Reese v Alberta (Minister of Forestry, Lands and Wildlife) (1992), 123 AR 241 (QB).

23 Downtown Eastside Sex Workers, ibid at paras 31-34.

$24 \quad$ Ibid at para 35. Public interest standing has been considered recently by an environmental assessment panel under the Canadian Environmental Assessment Act, 2012 to justify an expansive interpretation of those persons who are "directly affected" and thus entitled to participate in the assessment. See Olszynski, supra note 13 at 2. 
form since it is primarily concerned with excluding rather than inviting participants into the process, and is most closely aligned with public participation as espoused in liberal democracy where participation is limited to those who can demonstrate a personal right or interest is at stake in the outcome. It is thus worth noting that the question of participatory rights in resources and environmental decision-making is often referred to as a matter of standing by Alberta courts and project decision-makers. This is explored further in Parts III and IV.

The doctrine of procedural fairness is commonly thought to have originated in the 1863 English decision of Cooper v. The Wandsworth Board of Works ${ }^{25}$ wherein it was ruled a landowner had a right to be heard by a municipal authority that authorized the destruction of the landowner's house for a failure to comply with the municipal building code. The doctrine generally provides that a person has a legal right to know the case against him or her and an opportunity to meet that case before a public authority makes a decision that adversely affects that person's rights. The Supreme Court of Canada has affirmed on many occasions without referencing any explicit legal authority, that procedural fairness is a component of justice in the exercise of public power. ${ }^{26}$ Considered in this light, the rule in Wandsworth Board of Works simply encapsulates a norm of fundamental justice which itself transcends posited law. Whatever its origin, this legal right to be heard is the correlative of the legal obligation on the decision-maker to hear those affected by its decision. ${ }^{27}$

The scope of the doctrine was significantly narrowed during the first half of the twentieth century, and at the high point of contraction Canadian courts held only a statutory decisionmaker acting "judicially” was obligated to hear those affected by its decision. Even an executive order to expropriate lands did not trigger an obligation to hear the landowner whose land was taken. ${ }^{28}$ However the law was significantly reworked by a series of decisions from the Supreme Court of Canada between 1979 and 1999 that expanded the application of the procedural fairness doctrine. ${ }^{29}$ Today, where an administrative decision by a public authority may affect the rights, interests, or privileges of an individual, the decision-maker has a legal obligation to notify that individual of the decision to be made and provide that individual with an opportunity to be heard. Only clear statutory language will remove the application of this fairness obligation. ${ }^{30}$

The doctrine of procedural fairness is generally about ensuring participation in the exercise of public authority. The right to be heard extends beyond those persons with a property interest that may be affected by a decision, however it still generally only attaches to decisions that target specific individuals or groups and does not attach to policy decisions or other decisions of general application. ${ }^{31}$ So while the doctrine of procedural fairness is concerned with expanding participatory rights to a much greater extent than the doctrine of

(1863) 143 ER 414 [Wandsworth Board of Works].

See e.g. Dunsmuir v New Brunswick, 2008 SCC 9, [2008] 1 SCR 190 at para 90.

Wesley Newcomb Hohfeld, "Some Fundamental Legal Conceptions as Applied in Judicial Reasoning” (1913) 23:1 Yale L J 16.

Calgary Power Ltd v Copithorne, [1959] SCR 24.

Nicholson v Haldimand-Norfolk Reg Police Commrs, [1979] 1 SCR 311; Cardinal v Director of Kent Institution, [1985] 2 SCR 643; Knight v Indian Head School Division No 19, [1990] 1 SCR 653; Baker $v$ Canada (Minister of Citizenship and Immigration), [1999] 2 SCR 817.

Canada (Attorney General) v Mavi, 2011 SCC 30, [2011] 2 SCR 504 at para 39.

See e.g. Canadian Assn of Regulated Importers v Canada (Attorney General), [1994] 2 FC 247 (CA). 
standing, procedural fairness has not significantly influenced deliberations on the question of participation in resources and environmental decisions because, apart from the perspective of the project proponent, these tend to be decisions of general application.

The analysis in Part III will show the right to participate in resources and environmental project decision-making in Alberta today is essentially understood as a means to safeguard private interests against intrusion by public authority. The question of participation in project decision-making is framed as a standing determination, with the onus on the prospective participant to demonstrate a personal interest at stake in the proceedings. This framing works strongly against public participation in the pluralist sense, and in particular against participation by organized public interest groups or members of the public at large who seek to raise general, legal, or policy concerns and are unable to assert private rights will be adversely affected by a project decision.

\section{Public Participation in Resource Project ReViews}

Resources and environmental decision-making exists at several levels of public land management in Alberta, namely regional land-use planning, rights disposition, and project review. ${ }^{32}$ Public participation is a component of regional land-use planning and resource project reviews. There is no opportunity for public participation in the rights disposition process. ${ }^{33}$ Public consultation is required before a regional land-use plan is enacted under the Alberta Land Stewardship Act. ${ }^{34}$ However prior to the enactment of this legislation in 2009 there was no legal requirement for consultation in land-use planning. ${ }^{35}$ Generally speaking, a person seeking to participate in resources and environmental decision-making in Alberta must do so before a resource project decision-maker. Accordingly, this article focuses on public participation in resource project reviews.

Resource project decision-makers in Alberta include the Alberta Energy Regulator (formerly the Energy Resources Conservation Board), the Alberta ministry of Energy and Sustainable Resource Development (ESRD), the Natural Resources Conservation Board (NRCB), and the Alberta Environmental Appeals Board (EAB). ${ }^{36}$ The authority of these entities overlaps somewhat and, in the context of energy projects, is currently in transition. ${ }^{37}$ In May 2011 the Alberta government announced plans to consolidate energy project

Steven A Kennett \& Monique M Ross, “In Search of Public Land Law” (1998) CIRL Occasional Paper \#5, Canadian Institute of Resources Law at 9-20.

33 In relation to the disposition of oil and gas rights see Nickie Vlavianos, "Public Participation and the Disposition of Oil and Gas Rights in Alberta” (2007) 17:3 J of Envtl L \& Practice 205. See also Kennett \& Ross, ibid at 15.

SA 2009, c A-26.8, s 5.

Kennett \& Ross, supra note 32 at 11.

The Alberta Utilities Commission and a host of federal authorities including the National Energy Board, the Canadian Environmental Assessment Agency, the Department of Fisheries and Oceans, and Environment Canada could also be listed here. The decision-makers subject to this study were chosen because they are the primary provincial authorities for resources and environmental decision-making on public lands.

37 Nickie Vlavianos provides a detailed examination of the overlapping jurisdiction between Alberta Environment and the Energy Resources Conservation Board in the context of an oil sands recovery project. See Nickie Vlavianos, “The Legislative and Regulatory Framework for Oil Sands Development in Alberta: A Detailed Review and Analysis” (2007) CIRL Occasional Paper \#21, Canadian Institute of Resources Law at 30-57. 
decision-making into a single entity. ${ }^{38}$ That single regulator is now the Alberta Energy Regulator (AER), created in 2013 under the Responsible Energy Development Act. ${ }^{39}$

Taking this consolidation into account, resource project decision-making authority is generally split along the following lines. ESRD is responsible for the environmental assessment of a wide range of resource development and processing projects, as well as issuing approvals in relation thereto, under the Environmental Protection and Enhancement $A c t^{40}$ and the Water $A c t{ }^{41}$ Under REDA, the AER is intended to be the single regulatory agency responsible for approving all aspects of energy development projects, and accordingly the AER now has regulatory authority over energy-related approvals under the EPEA and the Water Act that were previously administered by ESRD, with the exception of authority over environmental impact assessments on energy projects which for now are reviewed jointly with ESRD. ${ }^{42}$ When this transition is complete, it will leave ESRD with responsibility over environmental assessments and project approvals for specified non-energy resource projects. For these projects, there remains overlap with the NRCB which is also responsible for approving non-energy resource development projects under the Natural Resources Conservation Board $\mathrm{Act}^{43}$ such as those related to forestry or recreation, as well as projects directed to the Board by executive order.

The EAB is an appellate body that hears appeals under the EPEA and the Water Act from project review decisions made by ESRD. Although not a project decision-maker per se, the EAB is included in this study because in the course of hearing appeals the Board has considered the question of public participation in resource project decision-making on numerous occasions.

This part examines how each of these decision-makers incorporates public participation in relation to a resource development project review. Each entity is either a creature of statute or exercises its power over resource projects under statutory direction. Where the governing statute requires decisions to be made in the public interest, a decision-maker arguably has the discretion to invite a broad spectrum of participation into its decision-making. ${ }^{44}$ As was noted earlier, the analysis set out here is less concerned with who may be invited to participate or whom the decision-maker may hear, but is rather focused on who has the legal right to participate or whom the decision-maker is obligated to hear. The fundamental issue explored here is whether a decision-maker responsible for furthering the public interest in resource development is obligated to hear from the public.

Government of Alberta, Enhancing Assurance: Developing an integrated energy resource regulator, a discussion document, May 2011 (2011), online: Alberta Energy <www.energy.alberta.ca/Org/pdfs/ REPEnhancingAssuranceIntegratedRegulator.pdf $>$.

SA 2012, c R-17.3, ss 2-3 [REDA].

RSA 2000, c E-12 [EPEA].

RSA 2000, c W-3.

This transfer of authority was made effective 29 March 2014 (Alberta Energy Regulator, "AER Bulletin 2014-08” (11 March 2014), online: <www.aer.ca/documents/bulletins/AER-Bulletin-2014-08.pdf>). RSA 2000, c N-3 [NRCB Act].

For example, Bankes makes this argument in respect of the Environmental Appeals Board in Nigel Bankes, "Shining a Light on the Management of Water Resources: The Role of an Environmental Appeal Board” (2006) 16:2 J of Envtl L \& Practice 131 at 170-71. 
The AER and the NRCB require a project proponent to engage in dialogue with the public on a proposed project before an application for approval is submitted to the agency. In relation to an energy project for example, the AER requires face-to-face consultation with landowners in close proximity. Common to each statute governing all the decision-makers examined here is a provision that provides a right of participation to, or alternatively an obligation on the decision-maker to hear, those persons who can demonstrate they may be directly affected by the resource development project in question. At some time or another each decision-maker under review here has provided its view on who meets the "directly affected" test for the right to participate in its decision-making process. The bulk of Part III consists of setting out and analyzing these interpretations to assess how each of these decision-makers views its obligation to hear public input.

The analysis begins with ESRD. This is because the EPEA provides the ministry with the broadest jurisdiction over project decision-making, including responsibility over environmental impact assessment for resource projects. This first segment of the analysis also includes an examination of the EAB since the Board hears appeals concerning resource project decisions made by ESRD. The analysis then examines participation before the AER. This examination includes the new legislative provisions governing public participation enacted in REDA, but since it is still early days for the AER and REDA the focus is primarily on how its predecessor - the Energy Resources Conservation Board — addressed public participation in an energy project review. The analysis concludes with the NRCB. In relative comparison to the other resource project decision-makers, the NRCB is called upon less frequently but nonetheless has considered public participation extensively. Part III concludes with some reflection on how these decision-makers view their obligation to hear public input.

\section{A. Public Participation at Alberta Environment And SUSTAINABLE RESOURCE DEVELOPMENT AND THE Alberta EnVIronmental APPEAls BoARD}

Alberta Environment and Sustainable Resource Development (ESRD) is responsible for the environmental assessment of a wide range of resource development and processing projects, as well as issuing approvals in relation thereto, under the EPEA and the Water Act. Specific types of projects subject to ESRD jurisdiction under the EPEA are listed in the Environmental Assessment (Mandatory and Exempted Activities) Regulation ${ }^{45}$ and the Activities Designation Regulation. ${ }^{46}$ ESRD is responsible for granting approvals under the Water Act for activities such as diverting surface or groundwater, draining wetlands, or amending existing licences to allow for new uses of diverted water. ESRD project approval decisions may be appealed to the EAB. ${ }^{47}$

The EPEA and the Water Act provide for the submission of public comments to ESRD in both the environmental assessment and the project approval stage. Section 6 of the

In cases where the subject matter of the appeal has already been considered in a hearing before the AER or the Natural Resources Conservation Board, the Environmental Appeals Board has no jurisdiction to hear the appeal. EPEA, supra note 40, s 95(5)(b). See also Carter Group v Director of Air and Water Approvals, Alberta Environmental Protection (8 December 1994), 94-012, online: EAB <www.eab. gov.ab.ca/dec/94-012.html>. 
Environmental Assessment Regulation ${ }^{48}$ requires that a project proponent give public notice of proposed terms of reference for an environmental assessment. In the case of a project which requires the approval of ESRD, section 72 of the EPEA requires either ESRD or the project proponent to give public notice of the application, and section 73 provides that a person who is directly affected by the application may submit a written statement of concern to ESRD regarding the application. The Water Act similarly prescribes the statement of concern procedure in section 109. The EPEA and the Water Act are silent on what is meant by the phrase "directly affected" in sections 73 and 109 respectively. The statement of concern process and the interpretation given to "directly affected" are crucial determinants of the right to participate before ESRD.

ESRD will only accept a statement of concern from a person who demonstrates they may be directly affected by the project application. Since the EPEA and the Water Act are silent on the meaning of "directly affected," ESRD arguably has full discretion to decide whether a person meets this test. ESRD issued policy in 1997 that suggested the ministry is receptive to public participation and would interpret "directly affected" in broad terms, however the Alberta Environmental Law Centre observed in 2001 that the ministry implements a more restricted approach in practice. ${ }^{49}$ In the course of this investigation, this policy was not found on the ESRD website. And in any event, it is difficult to identify with precision what factors ESRD actually takes into account in deciding whether a person is "directly affected" because, as the case study below demonstrates, the department does not typically provide any reasons for its decision to accept or reject a statement of concern.

The foregoing is the extent of public participation before ESRD in resource and environmental decision-making. Members of the public are entitled to submit written feedback on proposed terms of reference for an environmental assessment, but there is no opportunity for public input within the assessment process itself. The absence of public participation in the environmental assessment process is surprising given that an environmental assessment is a fact-finding exercise intended to inform subsequent decisions on whether to approve the resource development project, and as such would presumably benefit from a broad selection of viewpoints. However, the environmental assessment provisions in the EPEA appear to reflect the rational elitism view that resources and environmental decisions are exclusively the realm of experts and technocrats. The absence of reasons given by ESRD for approving or rejecting statements of concern makes it difficult to ascertain exactly what view the ministry has on the role for public input into its decisionmaking on resource development projects. ${ }^{50}$

Alta Reg 112/93.

Cindy Chiasson, "Drawing a Fine Line: The Adjudication of 'Directly Affected”” (2001) 16:3 News Brief 6, online: Environmental Law Centre <www.elc.ab.ca/Content_Files/Files/NewsBriefs/Vol.16 no.32001.pdf>.

In proceedings released just as this study was being completed, it was revealed that Alberta Environment has been rejecting statements of concern filed by environmental groups concerning oil sands projects on questionable grounds. In an August 2009 internal briefing note, Alberta Environment suggests the members of the Oil Sands Environmental Coalition are no longer simple to work with and less inclined to work cooperatively - making insinuating remarks on the use of legal process by these groups to oppose project approvals. The Pembina Institute attached the full text of the briefing note to its website. See Pembina Institute, "Court rules Alberta improperly excluded Pembina Institute from oilsands regulatory process” (2 October 2013), online: <www.pembina.org/media-release/2484>); briefing note of Alberta Environment to the Deputy Minister (12 August 2009), online: Pembina Institute $<$ www.pembina.org/reports/tab-19-august-12-2009-briefing-note.pdf>. 
Public participation in a decision by ESRD concerning a resource development project may also occur as part of appeal proceedings before the EAB. ${ }^{51}$ A person who previously submitted a statement of concern to ESRD concerning the project and who is directly affected by the ESRD decision may file a notice of appeal with the EAB. ${ }^{52}$ Upon receipt of a notice of appeal, the Board must conduct a hearing, either in person or by way of written submissions. ${ }^{53}$ However, as is the case with the statement of concern process before ESRD, this opportunity to participate is limited only to those persons who can demonstrate they may be directly affected by the project. The EPEA and the Water Act are also silent here on what is meant by the phrase "directly affected" in the applicable provisions. The EAB has provided its interpretation of "directly affected" in numerous decisions, and some of the more relevant decisions have been analyzed in the literature. ${ }^{54}$ No attempt will be made to duplicate that work here.

The EAB limits the right to participate to those who can demonstrate a personal right or interest that is discernible from a community interest and which may be harmed by the ESRD decision in question. The EAB looks for evidence setting out how a person uses the area in question, as well as how the project will affect that area and the person's use of it. The right to participate in decisions made by the EAB is thus a function of the causal proximity between the alleged harm on a person's beneficial interest(s) and the project or development in question. The first EAB decision to reflect this approach to participatory rights was its 1995 Kostuch decision wherein the Board dismissed an appeal by the late Martha Kostuch on the grounds her concerns were speculative or too remote. ${ }^{55}$ In the view of the EAB, Kostuch did not provide sufficient evidence of how the approval concerning a cement plant in the Rocky Mountain House region would affect her use of the region.

This interpretation suggests a public interest environmental group will have significant difficulty demonstrating it may be directly affected and accordingly has the right to participate before the EAB.$^{56}$ Such groups can rarely demonstrate a specific right or interest concerning the use of an area which is discernible from the community, and indeed they are often organized to serve as a vehicle for public engagement on community issues and thus by definition are not "directly affected." The EAB itself has stated it "has been the exception rather than the general rule" where a group satisfies the directly affected test. ${ }^{57}$

A review of EAB decisions that address group participation confirms this. Working from a database of EAB decisions that mention the word "group," 22 EAB decisions were

The EAB is established pursuant to section 90(1) of the EPEA, supra note 40. EPEA, ibid, s 91(1)(a)(i); Water Act, supra note 41, s 115(1)(c)(i).

EPEA, ibid, s 94.

The search term “directly affected” in a database of EAB decisions in Quicklaw produced 268 decisions since 1994 wherein the term is referenced (22 October 2013). For detailed commentary on the application of the directly affected test by the EAB see Bankes, supra note 44 at 162-71. The EAB employs a standard description of its interpretation of "directly affected" in its decisions, following the judicial interpretation of “directly affected” provided by the Alberta Court of Queen's Bench in Court v Environmental Appeal Board (Alta), 2003 ABQB 456, 333 AR 308.

Re Kostuch, [1995] AEABD No 9 (QL) [Kostuch].

Bankes, supra note 44 at 169-70. See also James Mallett, "Group Standing and the Environmental Appeals Board: The Latest Word” (2005) 20:1 News Brief 5, online: Environmental Law Centre $<$ www.elc.ab.ca/Content_Files/NewsBriefs/Vol.20-1.pdf $>$.

Re Jericho, [2004] AEABD No 36 (QL) at para 121. 
identified that address group standing. ${ }^{58}$ Of those 22 decisions, only two decisions grant standing to a community group. In a 1995 decision, the EAB granted standing to a community group representing concerned residents of the Hazeldean community in the City of Edmonton seeking to appeal a decision allowing a nearby facility to add a new source of emissions to its operations. ${ }^{59}$ The decision to grant standing to this group was based, in part, on survey evidence that indicated more than 50 percent of the residents in the community were concerned about the possible adverse effects from the new emissions. The Board concluded:

\footnotetext{
Herein lies the crux of the directly affected dilemma: how does an appellant discharge the onus of proving that he or she is directly affected when the nature of air emissions is such that all residents within the emission area may be directly affected to the same degree? One might be led to the conclusion that no person would have standing to appeal because of his inability to differentiate the affect upon him as opposed to his neighbour. This is unreasonable and it is not in keeping with the intent of the Act to involve the public in the making of environmental decisions which may affect them. ${ }^{60}$
}

There is no reference to personal rights and interests or evidence of causal connection in this decision, and the EAB expressly references public involvement in decision-making as a purpose underlying its governing legislation. ${ }^{61}$ It is noteworthy the Hazeldean decision predates the 1995 Kostuch decision, if only by a matter of weeks. The endorsement of participation by public interest groups would not continue beyond the Hazeldean decision. Subsequent EAB decisions confirm the 1995 Kostuch decision as the defining moment in how the EAB views the right to participate before it. In all subsequent decisions to allow community or public interest group participation before it, the EAB invites the group as a discretionary participant or an intervener to proceedings commenced by a person who met the "directly affected" test for standing. ${ }^{62}$

In order to update the literature concerning public participation before ESRD and the $\mathrm{EAB}$, and provide an illustration of the foregoing analysis, the following case study examines ESRD and EAB decisions in relation to an application to amend a water licence under the Water Act. Over the last decade or so ESRD has amended numerous water licences held by irrigation districts to allow them to allocate water for commercial purposes other than irrigation. On multiple occasions environmental groups have questioned the authority of ESRD to approve these amendments and have sought to participate in the amendment process to voice their concerns. The first of such attempts was made by the Southern Alberta Environmental Group with respect to an application by the St. Mary Irrigation District for

Based on a Quicklaw search. In isolating the 22 group standing decisions, cases were excluded where an individual was seeking to participate on behalf of a group.

Re Hazeldean Community League, [1995] AEABD No 5 (QL).

Ibid.

In the other decision to grant group standing, the $\mathrm{EAB}$ relied on evidence that individual members would meet the directly affected test as set out in Kostuch, supra note 55 and also that the group was formed specifically to participate before the Board. See Re Bailey, [2001] AEABD No 10 (QL) at paras 47-56. Section 95(6) of the EPEA, supra note 40, provides the EAB with the power to allow any person to appear before it and make representations. Decisions that have allowed group participation as such include: Re Zon, [1997] AEABD No 22 (QL); Re Kievit, [2002] AEABD No 41 (QL); Re Imperial Oil, [2002] AEABD No 49 (QL); Re Court, [2002] AEABD No 51 (QL); Re Doull, [2002] AEABD No 64 (QL); Re Mountain View Regional Water Services Commission, [2004] AEABD No 9 (QL); Re Gadd, [2005] AEABD No 18 (QL); Re Tartan Energy, [2005] AEABD No 32 (QL). 
an amendment to its 1991 licence to expand its allowable uses. ESRD and the EAB denied the group, or any other person for that matter, any opportunity to oppose the application. ${ }^{63}$

In 2010 three irrigation districts applied to ESRD for similar change-of-purpose licence amendments: the Eastern Irrigation District, Western Irrigation District, and Bow River Irrigation District. In each application, a trio of environmental groups and two individuals (collectively referred to as the "public interest participants" in the remainder of this case study) filed statements of concern with ESRD under section 109 of the Water Act. In each instance ESRD rejected the statement of concern on similar grounds that the group or individual was not directly affected and did not exist or reside within sufficient proximity to the area of water affected by the applied-for licence amendment. A sample of such reasoning is set out below from an ESRD letter addressed to one of the public interest participants:

Section 109(1) of the Water Act states that if notice is provided, any person who is directly affected by the application may submit a written Statement of Concern setting out their concerns with respect to the application. Your geographic location is outside the area associated with this proposed amendment. The Water Act requires that to be considered a Statement of Concern a person must be directly affected by the application. To be considered directly affected, a person must be able to demonstrate an interest that is directly impacted or harmed by this licence amendment application. On this basis, you will not be considered as directly affected and your submission will not be considered a Statement of Concern. ${ }^{64}$

Interestingly, ESRD is similarly brief when accepting a statement of concern. ESRD accepted the statement of concern filed by Walter Holoch, a rancher with property located within the eastern irrigation district. In accepting Holoch's statement of concern, ESRD told Holoch "[y]our letter is considered as an official Statement of Concern pursuant to the Water Act and, as such, you will be advised as to the Director's decision pertaining to this application." 65 This also demonstrates the earlier observation that participation before ESRD by a person who meets the "directly affected" test amounts to filing a written statement of concern and nothing more.

In November 2010, ESRD granted the change-of-purpose licence amendment requested by the Eastern Irrigation District, and ESRD did likewise for the Western Irrigation District and Bow River Irrigation District in 2011. The five public interest participants together with Holoch subsequently filed a notice of appeal with the EAB under section 115(1)(c) of the Water Act to challenge the Eastern Irrigation District licence amendment, and the five public interest participants alone filed similar notices of appeal to challenge the licence amendments granted to the Western Irrigation District and Bow River Irrigation District.

The Eastern Irrigation District licence amendment appeal was the first of the three to be considered by the EAB. In a preliminary motion to the EAB, ESRD challenged the standing

63 Re Jericho, [2004] AEABD No 36 (QL). For further discussion see Nigel Bankes \& Arlene Kwasniak "The St. Mary's Irrigation District Licence Amendment Decision: Irrigation Districts as a Law unto Themselves” (2005) 16:1 J Envtl L \& Practice 1.

$64 \quad$ Letter from Alberta Environment to Alberta Wilderness Association (1 September 2010) in the EAB hearing record for Eastern Irrigation District Water Act Licence Amendment Application No. 0007106600-01.

65 Letter from Alberta Environment to Walter Hohloch (1 September 2010) in the EAB hearing record for Eastern Irrigation District Water Act Licence Amendment Application No. 00071066-00-01. 
of all five public interest participants and Holoch as not being directly affected persons. Accordingly, the EAB began its Eastern Irrigation District proceedings asking for written submissions on standing. The EAB issued its standing decision in August 2011, ruling that none of the public interest participants were directly affected by the licence amendment and thus had no standing to appeal the licence amendment. ${ }^{66}$ The EAB ruled the concerns raised by the public interest participants which questioned the authority of ESRD to approve the licence amendment and the implications of such approvals for their ongoing policy and advocacy work does not constitute a personal right or interest that may be affected by the ESRD decision. ${ }^{67}$ Moreover, in order to demonstrate the requisite personal impact called for by the legislation, individual members of a group applicant must demonstrate they may be personally affected. ${ }^{68}$

The public interest participants also argued, in the alternative, that the EAB grant them public interest standing to appear before the Board. The groups advanced two statutory interpretation arguments to support their view a person need not be "directly affected" to appear before the EAB, namely that section 95(6) of the EPEA gives the Board power to allow any person to appear before it and also that nowhere in the legislation is it stated that the Board is obligated to dismiss an appeal filed by a person who is not directly affected. Accordingly, the public interest participants argued the EAB has the power to grant public interest standing in accordance with the established criteria in the jurisprudence. ${ }^{69}$ The EAB ruled it does not have jurisdiction to grant public interest standing. ${ }^{70}$ The public interest participants were thus completely excluded from participating before the EAB to challenge the legality of the licence amendments.

\section{B. Public Participation at the Alberta Energy Regulator AND ITS PREDECESSOR ENERGY RESOURCES CONSERVATION BOARD}

The AER was established in 2013 pursuant to section 3 of $R E D A^{71}$ and is intended to be the single regulatory authority responsible for the approval and ongoing oversight of energy resource projects in Alberta. The AER replaced the Energy Resources Conservation Board (ERCB). ${ }^{72}$ In addition to REDA, the AER obtains its regulatory authority from several resource-specific statutes including the Oil and Gas Conservation Act. ${ }^{73}$

None of the rules pertaining to mineral rights disposition or surface access to construct energy facilities provide for public participation. ${ }^{74}$ As was noted above, there is little opportunity for public input in the environmental assessment process administered by ESRD.

66
67
68
69
70
71
72

Re Alberta Wilderness Assn, [2011] AEABD No 18 (QL) [Alberta Wilderness Assn].

Ibid at paras 135-43.

Ibid at para 134 .

For a discussion of public interest standing see supra note 22 and accompanying text.

Alberta Wilderness Assn, supra note 66 at paras 154-60.

Supra note 39.

The agency responsible for the regulation of energy projects has changed its name several times since the 1930s when the Alberta government formed the Petroleum and Natural Gas Conservation Board to regulate the burgeoning oil and gas industry. David H Breen sets out the history in Alberta's Petroleum Industry and the Conservation Board (Edmonton: University of Alberta Press, 1993). 2000, c C-17 and the Oil Sands Conservation Act, RSA 2000, c O-7.

Vlavianos, supra note 33. 
Accordingly, if there is to be any public participation in energy project decision-making it must occur at the AER.

Public participation ostensibly begins with the AER requirement that a project proponent implement a community participation program before making its application for project approval. ${ }^{75}$ The AER expects this program to include notification and dialogue with various stakeholders in the surrounding area including local authorities, public interest groups, holders of other dispositions, and any other person who expresses an interest in the project. ${ }^{76}$ The AER specifically requires an energy company to conduct face-to-face consultation with the landowner and resident (if different from the owner) of the land upon which the project will be located, as well as owners of land within a prescribed radius of specified projects. ${ }^{77}$ The prescribed radius varies from as little as 100 metres to as far as several kilometres, depending on the nature of the energy project in question. The prescribed face-to-face consultation radius for a conventional sweet gas well, for example, is 300 metres from the well site. ${ }^{78}$ The AER requires a project proponent to disclose any unresolved objections concerning the proposed project in its application to the AER. ${ }^{79}$

The legislative rules governing public participation before the AER are currently in transition from the now-repealed Energy Resources Conservation $A c t^{80}$ to REDA and its underlying subordinate legislation. It is too early to assess fully how public participation will unfold under REDA but some preliminary observations are made at the end of Part III.B. This transition does, however, present an opportunity to bookend the right to public participation as it existed at the ERCB under the Energy Resources Conservation Act, and that is where the analysis begins. One caveat here is that a complete review of all ERCB or AER decisions on public participation is not feasible because such decisions are typically set out only in letters sent directly to persons seeking to participate.

For decades prior to the enactment of REDA, public participation before the ERCB was governed by section 26 of the Energy Resources Conservation Act:

(1) Unless it is otherwise expressly provided by this Act to the contrary, any order or direction that the Board is authorized to make may be made on its own motion or initiative, and without the giving of notice, and without holding a hearing.

(2) Notwithstanding subsection (1), if it appears to the Board that its decision on an application may directly and adversely affect the rights of a person, the Board shall give the person

(a) notice of the application,

(b) a reasonable opportunity of learning the facts bearing on the application and presented to the Board by the applicant and other parties to the application,

AER, Directive 056: Energy Development Applications and Schedules (1 September 2011), s 2.2.1, online: AER <www.aer.ca/rules-and-regulations/directives/directive-056>.

Ibid.

Ibid, s 2.3.1.

Ibid.

Ibid, s 3.8.2.

RSA 2000, c E-10, as repealed by REDA, supra note 39, s 112 . 
(c) a reasonable opportunity to furnish evidence relevant to the application or in contradiction or explanation of the facts or allegations in the application,

(d) if the person will not have a fair opportunity to contradict or explain the facts or allegations in the application without cross-examination of the person presenting the application, an opportunity of cross-examination in the presence of the Board or its examiners, and

(e) an adequate opportunity of making representations by way of argument to the Board or its examiners.

Prior to its repeal in 2013, the section 26(2) “directly and adversely affected” test had been in force since 1969 when the Alberta government added it as section 110(2) to the Oil and Gas Conservation Act. ${ }^{81}$ Prior to 1969 the ERCB had complete discretion to decide when to conduct a hearing. ${ }^{82}$

When faced with a request for a hearing by a person, typically the case where the community participation program administered by a project proponent fails to resolve outstanding objections to the project, section 26(2) of the Energy Resources Conservation Act imposed an obligation on the ERCB to form an opinion on whether its project decision may directly and adversely affect the rights of the person. By the time it ceased to exist in 2013, the ERCB had constructed a very narrow view of those persons capable of meeting the "directly and adversely affected" test in section 26(2) and the Board seemed very reluctant to engage in public participation.

To begin with, it is noteworthy the ERCB was not always so restrictive in its approach to participation in energy project decision-making. In his early study of public participation in Alberta resource development decision-making, Elder commented on a "liberal" interpretation given by the ERCB to persons capable of meeting the "directly and adversely affected” test:

Public participation is an integral part of the Board's procedure.

The Board, under its rules of procedure, takes a broad view of its mandate, and generally, where protests are lodged after advertising, the Board will hold a hearing. It also liberally interprets the question of direct and adverse affect in favour of the intervener so long as the intervener has “a bona fide interest”. Indeed, for developments such as gas plants, all land owners within a two mile radius are given notice and there are mailing lists of oil companies and environmental groups as well. ${ }^{83}$

A paradigmatic example of this approach to public participation at the ERCB in earlier times is the 1986 hearing to consider a Shell Canada application for a licence to drill a sour gas well on public lands in southwestern Alberta. ${ }^{84}$ Part of the significance attaching to this

81 The Oil and Gas Conservation Act, 1969, SA 1969, с 83.

82 Earlier versions of section 26 had been in force since the creation of the Petroleum and Natural Gas Conservation Board in 1938. See e.g. The Oil and Gas Resources Conservation Act, SA 1938, c 83, s 47(1).

$83 \quad$ Elder, supra note 1 at 424-25.

$84 \quad$ ERCB, A Report on an Application by Shell Canada Limited to Drill a Critical Sour Gas Well in the Jutland (Castle River South) Area (Calgary: ERCB, 1986). 
application was that it was the first gas well in the region, and there were no landowners (other than the Crown) or residents in the vicinity. At the hearing the ERCB received submissions from a wide range of environmental interveners including Parks Canada, the Alberta Wilderness Association, the Canadian Parks and Wilderness Society, and several United States environmental groups. These groups and individuals opposed the Shell application because they believed the well would destroy the wilderness character of the region and the environmental values inherent therein.

Subsequent proceedings further suggest public participation before the ERCB was not at issue during the 1980s and early 1990s. In 1988 the ERCB convened a hearing to consider another contested application by Shell Canada to drill a gas well in the foothills of southwestern Alberta, and a similar group of public participants made submissions to the Board in the hearing. ${ }^{85}$ Likewise in 1994 the ERCB heard from a variety of public participants including environmental groups, First Nations, and local municipalities in a hearing to consider an application by Amoco Canada to drill a gas well near the Oldman River in southwestern Alberta. ${ }^{86}$ These decisions do not confirm whether or not the ERCB felt obligated to include broad public input in its review of the subject applications, but nonetheless it is important to note these proceedings concerned energy projects located on public lands far removed from residents or other persons who would fall within the Board's face-to-face consultation radius. At a minimum, these decisions show the ERCB was not excluding public participants.

Based on publicly available information it is not possible to pinpoint an exact date when the ERCB began to restrict participation to those persons who reside or own land in close proximity to the project in question. The "directly and adversely affected" test set out in section 26(2) of the Energy Resources Conservation Act remained unchanged from 1969 until 2013, but at some point during that timeframe the ERCB began to interpret and apply section 26(2) as a "standing" test to limit participation in energy project applications to those in close proximity. Restrictions on public participation are apparent in written decisions dating back to at least 2003.

In a 2003 hearing to consider an application by Polaris Resources to drill a sour gas well in the same region as the earlier applications described above, the ERCB allowed all residents within the prescribed consultation radius and landowners within 1.5 kilometres of the well to participate fully at the hearing. ${ }^{87}$ The ERCB granted other members of the public the opportunity to express concerns at the hearing but denied them an entitlement to submit evidence or cross-examine Polaris:

The Board is of the view that residents located within the $13.54 \mathrm{~km}$ calculated EPZ radius of the well and landowners within $1.5 \mathrm{~km}$ of the well have standing for the purposes of participating at the public hearing under Section 26 of the Energy Resources Conservation Act. (ERCB).

Application for an Exploratory Well - Amoco Canada Petroleum Company Limited, Whaleback Ridge Area (6 September 1994) 94-8 (ERCB).

87 Pre-hearing meeting - Applications for a licence to drill a sour gas well, compulsory pooling, and special well spacing orders - Polaris Resources - Livingston Field (30 April 2003), 2003-30 (AEUB), online: AER <www.aer.ca/documents/decisions/2003/2003-030.pdf>. 
Those parties who have registered their interest and who fall outside of the $13.54 \mathrm{~km}$ radius may participate at the hearing but, depending on whether they have joined a group with standing, their participation may be limited to presenting a short statement of their position. They would not have full participation rights, such as leading evidence, cross-examining witnesses, and giving final argument. ${ }^{88}$

By 2006 the ERCB was applying the “directly and adversely affected” test in section 26(2) to exclude public participation altogether in energy project applications. In a June 2006 decision, the ERCB denied participatory rights to a number of individuals, groups, and the Municipal District of Pincher Creek which sought to express concerns to the Board on an application by Compton Resources to drill a gas well in the foothills of southwestern Alberta. ${ }^{89}$ Compton obtained the consent from the owner of the lands upon which the well was to be drilled, and subsequently argued that none of the other parties were entitled to a hearing. ${ }^{90}$ The ERCB accepted this argument, and provided several justifications for its ruling: the closest residents to the well, not including the consenting landowner, were at least 1.2 kilometres from the well site and were located beyond the face-to-face consultation radius prescribed by its own directives; the Municipal District of Pincher Creek had general concerns that were not specific to the well facility; the Alberta Wilderness Association would not be affected to a greater or lesser degree than the public generally; and the membership of the Pekisko Group did not include an owner of land or resident in sufficient proximity to the well site. ${ }^{91}$

In 2007 a large number of persons objected to the drilling of a sour gas well by Shell Canada near the hamlet of Beaver Mines in southwestern Alberta. In a pre-hearing decision the ERCB further refined its view on "standing” to appear before the Board:

In making a determination as to whether a person has standing under this section, the Board has adopted a two-part test. The Board will first determine whether a person has a legally recognized interest or right and, second, whether the information provided by that person shows that the applications before the Board may directly and adversely affect that interest or right.

In regard to Shell's proposed well and pipelines, the Board is satisfied that the persons who reside within the proposed $6.9 \mathrm{~km}$ EPZ for the well and have submitted an objection have shown that they have a legal interest or right and that that interest or right may be directly and adversely affected. The Board formed this opinion on the basis of these persons' proximity to the proposed well and pipelines, the fact that the proposed well and one of the pipelines will be classified as level 3 and a level 2 respectively, and the nature of the issues raised regarding the potential direct and adverse impacts on their legal interest or right. In addition, the Board

Decision on requests for consideration of standing respecting a well licence application by Compton Petroleum Corporation - Eastern Slopes Area (8 June 2006), 2006-052 (AEUB), online: AER $<$ www.aer.ca/documents/decisions/2006/2006-052.pdf>.

Ibid at 7-8. 
notes that Shell agreed that these individuals would have standing with respect to these applications. Therefore, the Board has granted standing to these persons to participate in the hearing. ${ }^{92}$

This excerpt demonstrates that by 2007 the ERCB had developed a standard approach to deciding questions of participation — or standing as the ERCB puts it — which Part IV will show was endorsed by the Alberta Court of Appeal. Somewhat more problematic, this excerpt also suggests the views of the project proponent influenced the ERCB's view on who it was obligated to hear in these proceedings. Of note on this point, Shell Canada had opposed the participation of Michael Sawyer who sought to participate as a concerned member of the public who used the area for recreational purposes but was not a resident within the prescribed consultation radius. ${ }^{93}$

Sawyer objected to the proposed well on grounds that he used the region for recreational purposes and that the sour gas facilities would elevate his exposure to health and safety risks when visiting the area. The ERCB denied him standing, and gave the following reasons:

\begin{abstract}
Mr. Sawyer is a recreational user of the public lands in the area and visits friends. However, he and his family do not reside near the proposed well or pipelines. Therefore, they would not be subject to the potential direct and adverse impacts claimed, unless they choose to frequent the area. This is not the case for residents who are within the EPZ. Also, the proposed well and pipelines are within the vicinity of other wells and pipelines producing or transporting gas containing $\mathrm{H}_{2} \mathrm{~S}$. This type of well and pipeline is not new to the area. Therefore, the Board believes Mr. Sawyer failed to establish that the potential impacts may affect his and his family's safety differently or to a greater degree than that of any other member of the public using the area for recreation or visiting friends. He has not demonstrated the connection between the proposed well and pipelines and a potential direct and adverse impact on his and his family's health or safety. ${ }^{94}$
\end{abstract}

The ERCB denied Sawyer the opportunity to participate on the basis that the well would not affect him in a different manner from that of the public generally. The ERCB ruled similarly against the participation by the Castle-Crown Wilderness Coalition. ${ }^{95}$

What is perhaps most notable is that more or less the same group of persons had no difficulty participating before the ERCB in hearings concerning wells in the same region during the 1980s and 1990s. In the passage of time the ERCB became increasingly averse to public participation before it and, with the odd exception, ${ }^{96}$ the ERCB was applying the “directly and adversely affected" test in its governing legislation to deny participatory rights to anyone other than landowners or residents within a consultation radius prescribed in the

Prehearing meeting - applications for a well and associated pipeline licences - Shell Canada Waterton Field (27 June 2007), 2007-053 at 3 (AEUB) [emphasis added], online: AER <www. aer.ca/documents/decisions/2007/2007-053.pdf>.

Ibid at 4 .

Ibid at 5 .

Ibid at 5 .

These exceptions would include energy project reviews conducted jointly between the ERCB and federal environmental assessment authorities where public participation was governed by the Canadian Environmental Assessment Act, supra note 9. For some discussion see supra notes 9, 10 and accompanying text. See e.g. Report of the Joint Review Panel Established by the Federal Minister of the Environment and the Alberta Energy and Utilities Board - Decision 2009-008: Encana Shallow Gas Infill Development Project (Calgary \& Ottawa: ERCB \& Canadian Environmental Assessment Agency, 2009), online: AER <www.aer.ca/documents/decisions/2009/2009-008.pdf>. 
Board's own directives who could also demonstrate the energy project may affect them personally and in a manner different from the public generally.

Section 26 of the Energy Resources Conservation Act was repealed and replaced with the enactment of REDA in 2013. It is too early to assess fully how public participation will unfold under REDA but some preliminary observations can be made based on the new provisions in the legislation.

The relevant provisions of REDA governing public participation at the AER are sections 32, 33(1), and 34:

32 A person who believes that the person may be directly and adversely affected by an application may file a statement of concern with the Regulator in accordance with the rules.

33(1) Where a statement of concern is filed in respect of an application, the Regulator shall decide, in accordance with the rules and subject to section 34 , whether to conduct a hearing on the application.

34(1) Subject to subsection (2), the Regulator may make a decision on an application with or without conducting a hearing.

(2) The Regulator shall conduct a hearing on an application

(a) where the Regulator is required to conduct a hearing pursuant to an energy resource enactment,

(b) when required to do so under the rules, or

(c) under the circumstances prescribed by the regulations.

(3) If the Regulator conducts a hearing on an application, a person who may be directly and adversely affected by the application is entitled to be heard at the hearing.

(4) A hearing on an application must be conducted in accordance with the rules.

The first observation is that the provisions of REDA alone do not provide a legal right to participate in front of the AER. Section 34(2) obligates the AER to conduct a hearing only in circumstances where another enactment requires the hearing. An "energy resource enactment" is defined in REDA to mean the various energy sector-specific statutes such as the Oil and Gas Conservation Act, ${ }^{97}$ and none of these statutes require the AER to hear public concerns. Sections 6.2 and 7 of the Alberta Energy Regulator Rules of Practice ${ }^{98}$ set out factors the AER may consider in deciding whether to conduct a public hearing on an energy project application. ${ }^{99}$

REDA, supra note 39, s 1(1)(j).

Alta Reg 99/2013.

For some commentary on these factors and their potential impact on the right to participate in AER proceedings see Shaun Fluker, “Amended Rules of Practice for the Alberta Energy Regulator: More Bad News for Landowners and Environmental Groups” (11 December 2013), Ablawg.ca (blog), online: <ablawg.ca/2013/12/11/amended-rules-of-practice-for-the-alberta-energy-regulator-more-bad-news-forlandowners-and-environmental-groups/>. 
The second observation is that REDA brings the statement of concern process to the AER that was examined earlier in relation to ESRD and the EAB. A person who feels he or she may be directly and adversely affected by an energy project must initially file a statement with the AER documenting the concern(s). Failure to properly file a statement of concern with the AER extinguishes any possibility of participation before the AER under REDA.

The final observation is that participation by a member of the public or interest group is dependent on three favourable determinations by the AER: (1) the AER forms the opinion the person filed a statement of concern in accordance with section 32 of REDA and the Alberta Energy Regulator Rules of Practice; (2) the AER forms the opinion that statement of concern demonstrates the person may be directly and adversely affected by the energy project; and (3) the AER decides to conduct a hearing. In the case where the AER decides not to conduct a hearing in relation to an energy project review, public participation at the AER amounts only to obtaining publicly disclosed information about the proposed energy project and filing a statement of concern with the agency.

\section{Public Participation at the NATURAL RESOURCES CONSERVATION BOARD}

The Natural Resources Conservation Board (NRCB) came into existence in 1991 at a time when the Alberta government overhauled its regulatory framework governing environmental management. The agency was created to review project proposals for non-energy resource development and assess whether such development is in the public interest. The NRCB still holds this public interest mandate over non-energy resource projects, but today the NRCB also regulates some aspects of feedlot operations and serves as an appellant body under the Agricultural Operation Practices Act ${ }^{100}$ concerning approvals and inspections of commercial feedlots. The two mandates are kept distinct within the NRCB, and this study only looks at its jurisdiction over non-energy resource projects.

The resource projects within the public interest jurisdiction of the NRCB are prescribed by section 4 of the NRCB Act. ${ }^{101}$ These prescribed projects include pulp and paper, water storage, quarry, and recreational projects, for which an environmental impact assessment is required under the EPEA. In addition to this prescribed list, the NRCB has jurisdiction to review a project assigned to it by executive order. The NRCB is responsible for assessing whether a reviewable project is in the public interest, having regard for its social, economic, and environmental effects. ${ }^{102}$ No person may commence a reviewable project without the approval of the NRCB. ${ }^{103}$

The review of a non-energy resource project by the NRCB is typically by way of public hearing, although section 8 in the NRCB Act only obligates the NRCB to do so where the project may directly affect a person. The relevant portions of section 8 read as follows: 
8(2) The Board shall give persons who may be directly affected by a proposed project, and may give any other persons it considers necessary,

(a) a reasonable opportunity of reviewing the information relevant to the application that is submitted to the Board by the applicant and the other parties to the application,

(b) a reasonable opportunity to furnish evidence relevant to an application or in contradiction or explanation of the information referred to in clause (a),

(c) if the person will not have a fair opportunity to contradict or explain the information referred to in clause (a) without cross-examination of the person who submitted it, an opportunity to cross-examine that person in the presence of the Board, and

(d) an adequate opportunity of making representations by way of argument to the Board.

(3) Where the Board receives a written objection in respect of an application and the objection is submitted by a person who the Board considers is directly affected by the proposed project, the Board shall hold a hearing in respect of the application unless it considers the objection to be vexatious or of little merit.

Similar to the policies of the AER applicable to an energy project, the NRCB requires non-energy project proponents to communicate with the public to identify and possibly resolve outstanding issues concerning a project before submitting an application for Board approval. ${ }^{104}$ References in various decision reports confirm the NRCB considers the adequacy of a proponent's prior consultation during its initial review of an application. In the words of the NRCB, "[a]chieving sustainable natural resource developments that reflect the public interest requires collaboration with the people and communities who may be directly affected.”105

The proof of the pudding is in the eating. The NRCB lists 16 completed resource project decisions on its website: five decisions on projects referred to it by executive order; one decision on a waste paper recycling facility; three decisions on quarry and other miningrelated projects; three decisions on recreational projects; and four decisions on water diversion projects. For the purposes of this study, the water diversion projects were not considered because these decisions are based on joint proceedings between the NRCB and federal environmental assessment authorities. Of the remaining 12 NRCB resource project decisions, seven include evidence of public participation at the NRCB. 
Public participation is most evident in the decision-making process concerning recreational projects. ${ }^{106}$ Each application involves a proposal to construct a resort in the Rocky Mountains offering recreational facilities such as skiing, golfing, and on-site accommodation. In each case, the project faced opposition from environmental groups and others who argued, among other things, the development would destroy wildlife habitat. The NRCB held public hearings to consider these projects, and the hearing record for each project suggests any person wishing to participate in the hearing was allowed to do so. In the prehearing report concerning the Three Sisters Golf Resort project near Canmore, the NRCB goes so far as to state "members of the public, or groups of members of the public, wishing to provide evidence about an application before the Board or to ask questions of an applicant, are entitled to do so." ${ }^{\text {"107 }}$

Public participation is also evident in the decision-making process concerning the five projects referred to the NRCB by executive order. These projects involve large-scale processing of extracted resources or hazardous waste. ${ }^{108}$ Participants in the NRCB hearing process concerning four of these referred projects include nearby residents, either as individuals or organized groups, but also others who do not reside in close vicinity to the proposed facility as well as First Nations, environmental groups, and municipalities. However, in one of these project reviews the NRCB relied on the "directly affected" test in section 8(2) of the NRCBAct to dismiss objections filed against the project and subsequently approved the project without a public hearing. ${ }^{109}$

None of the forestry or mining projects before the NRCB for approval has been subject to a public hearing. In one case the NRCB dismissed objections against the project on the basis the person(s) objecting would not be directly affected by the project, and then proceeded without a public hearing. ${ }^{110}$ In the other three cases, the NRCB notes that either

See e.g. "Kan-Alta Golf Management Ltd — Golf Course at Evan Thomas Creek,” online: NRCB <https://nrp.nrcb.ca/Projects/CompletedProjects/KanAltaGolfManagement.aspx>; "Three Sisters Golf Resorts Inc - Three Sisters Recreational and Tourism Project, Canmore,” online: NRCB <https:// nrp.nrcb.ca/Projects/CompletedProjects/ThreeSistersGolfResorts.aspx>; "Vacation Alberta Corp Westcastle Four Season Resort Project,” online: NRCB <https://nrp.nrcb.ca/Projects/Completed Projects/VacationAlbertaCorp.aspx>.

107 Three Sisters Golf Resorts Inc (9 March 1992) at 7 (report of pre-hearing), online: NRCB <https://nrp. nrcb.ca/Portals/1/Documents/Decisions/Three-Sisters/pre-hearing.pdf>.

108 See e.g. "Chem Security (Alberta) Ltd — Swan Hills Special Waste Treatment Centre, online: NRCB <https://nrp.nrcb.ca/Projects/CompletedProjects/ChemSecurityLtdSwanHills.aspx>; "Chem Security (Alberta) Ltd - Treatment of Hazardous Waste From Other Provinces,” online: NRCB <https://nrp. nrcb.ca/Projects/CompletedProjects/ChemSecurityLtd.aspx>; “Agrium Products Inc — Extension of Existing Gypsum Storage Area,” online: NRCB <https:/nrp.nrcb.ca/Projects/CompletedProjects/ AgriumProducts.aspx>; "Arclin (formerly Dynea Canada Ltd) — Formaldehyde Production Plant," online: NRCB <https://nrp.nrcb.ca/Portals/1/Documents/Decisions/Arclin/Decision-report.pdf>; "Alberta Sulphur Terminals Ltd/Hazco Environmental Services — Sulphur Forming and Shipping Facility,” online: NRCB <https://nrp.nrcb.ca/Projects/CompletedProjects/AlbertaSulphurTerminals Ltd.aspx>.

Arclin Canada Ltd - Formaldehyde Production Plant, Sexsmith, (September 2008), $2008-02$ (at 3) NRCB.

110 Hammerstone Corporation - Hammerstone Quarry Project in the Fort McMurray area (June 2010), NR 2010-01, online: NRCB <https://nrp.nrcb.ca/Portals/1/Documents/Decisions/Hammerstone/ Hammerstone-decision.pdf $>$. The NRCB likewise dismissed an objection against a quarry project application listed as a "current” as opposed to “completed” project as of April 2014, and subsequently approved the application without a public hearing. See Parsons Creek Aggregates Limestone Quarry Project near Fort McMurray (February 2014), NR 2014-01, online: NRCB <https://nrp.nrcb.ca/ Portals/1/Documents/Projects/Parsons/Board-Decision-NR2014-01-1001.pdf>. 
no objections were filed or the person objecting did not wish to proceed with a hearing and accordingly the NRCB decided the matter without a public hearing. ${ }^{111}$

An examination of all 12 NRCB resource project decisions included in this study reveals a notable distinction between how the NRCB handles public participation in the recreational projects on the one hand and industrial projects on the other. Public participation seems to be a matter of course in the NRCB decision-making process for the recreational projects, and the Board's endorsement of public input seems to reflect a pluralist view on public participation in its decision. The record on industrial projects is somewhat mixed on public participation, and these decisions suggest a more reserved position from the Board. In particular, the NRCB relies on the "directly affected" test to preclude participation in some of these decisions.

What accounts for this distinction is left for speculation. The legal and policy framework governing resource project reviews by the NRCB does not distinguish between project categories in relation to public participation; the "directly affected" test contained in section $8(2)$ of the NRCB Act applies to both recreation and industrial project reviews. However, a couple of observations are in order. The recreational project applications were all before the NRCB early in its tenure, and perhaps came at a time when the Alberta government was more receptive to public participation in resource project reviews. Similarly the fact that most projects referred to the NRCB by executive order involve public participation may be simply because the project has been referred to the NRCB for the purpose of adding a measure of transparency to the decision-making process.

In those cases where the NRCB has relied on the "directly affected" test in section $8(2)$ of the NRCB Act to exclude participation, the Board has done so without providing an interpretation of what "directly affected" means. However, the NRCB has provided its interpretation of the phrase as it relates to the entitlement for participant funding in section 11 of the NRCB Act. ${ }^{112}$ In the 1992 pre-hearing decision concerning the Three Sisters Golf Resort the NRCB ruled that in order to satisfy the Board that a project may or will directly affect a person, that person must demonstrate: (1) there is an uninterrupted chain of cause and effect between the project and the person; (2) the effect is likely to occur; and (3) the effect will not be trivial. ${ }^{113}$ In a more recent 2009 project review, the NRCB added that "direct affect" in section 11 does not include effects on the public generally, but rather is an effect that is "different, special or unique from effects on the general public."114

111 Consumers Paper Corporation - Waste Paper Recycling Facility in the Town of Redcliff, Alberta (1993) (decision report), online: NRCB <https://nrp.nrcb.ca/Projects/CompletedProjects/Consumers PaperCorp.aspx>; "United Industrial Services Ltd — Silica Mine,” online: NRCB <https://nrp.nrcb.ca/ Projects/CompletedProjects - UnitedIndustrialServices.aspx>; Birch Mountain Resources Ltd Muskeg Valley Quarry Project Fort McMurray Area, Alberta (June 2005), NR 2005-01, online: NRCB $<$ https://nrp.nrcb.ca/Portals/1/Documents/Decisions/Birch-Mountain/decision-report.pdf>.

112 Section 11(1) of the NRCB Act, supra note 43, states "Individuals or groups of individuals who, in the opinion of the Board, are or may be directly affected by a reviewable project are eligible to apply for funding under this section.”

113 Three Sisters Golf Resorts Inc, supra note 107 at 17. The NRCB has subsequently applied this test in other decisions. See e.g. Agrium Products Inc (17 December 2003) at 3 (pre-hearing meeting report), online: NRCB <https://nrp.nrcb.ca/portals/1/documents/decisions/agrium/pre-hearing.pdf >. 2009) at 8 (pre-hearing meeting decision report), online: NRCB <https://nrp.nrcb.ca/Portals/1/ Documents/ Decisions/Alberta-Sulphur/Sulphur-pre-hearing-report.pdf $>$. 


\section{Concluding Thoughts on Public Participation in Resource Project ReVIEWS}

Generally speaking, a person seeking to participate in resources and environmental decision-making in Alberta must do so before a public authority with decision-making power to approve resource projects. Common to the legislation governing each of these decisionmakers is a provision that grants participatory rights to those persons who can demonstrate they may be directly affected by the resource development project in question. The exception here is the recently enacted REDA which does not obligate the AER to hear directly and adversely affected persons.

Each decision-maker has at some point interpreted the "directly affected" provision in their governing statute in a similar manner, such that it is possible to make the following general observations about the right to participate in resources and environmental project decisions in Alberta: (1) a person who seeks to participate must demonstrate how the project may affect them personally; and (2) the right to participate is a function of causal proximity between the affected person and the location of the project in question - the closer one is to the project or the more apparent the causal link between the alleged impact and the project, the more likely that person will be entitled to participate in the decision-making process.

The question of the right to public participation has arisen from the fact these decisionmakers have increasingly interpreted the "directly affected” provision in their governing legislation to exclude all but a narrow class of persons from the decision-making process. The examination of ERCB decisions spanning several decades, in particular, illustrates a clear shift away from participation in a pluralist sense. In an earlier time, energy development projects located on remote Crown lands were nonetheless subject to wide public scrutiny. Commentators remarked about growth in public participation at the ERCB and the Board's generous interpretation of persons and groups who may be directly and adversely affected by an energy project.

Alberta resources and environmental project decision-makers now control who participates before them using a preliminary standing determination in cases where a resource development project is contested. Their interpretation of the "directly affected" test for participation correlates with the common law test for standing to initiate proceedings in either private or public law. The right to participate in the decision-making process is thus held only by those persons who can demonstrate the decision may have a direct, personal impact on them. Public participation in resources and environmental project decision-making is essentially then a means to safeguard private interests against harm emanating from the exercise of public authority. Understood as such, the right to participate is hard to distinguish from traditional common law measures that similarly purport to protect private interests in the liberal state. Environmental and other public interest groups as well as individual members of the public-at-large who are unable to assert the requisite private interest in a project decision have, in result, been excluded from participation in resource project decision-making in Alberta, save for those cases where they have been invited to participate. General public concerns about a resource project are presumptively the domain of the Crown. 
The case study set out in Part III.A concerning participatory rights at the EAB demonstrates Crown officials have aggressively challenged the standing of a person who seeks to raise legal or policy concerns about a resource development project in Alberta, arguing these concerns are not sufficiently direct, personal, or unique from the public generally. Similarly where the decision-makers examined here have given reasons for denying "standing" to a person or group, in some cases there is language in the decision to suggest that project proponents also challenge the standing of persons seeking to raise general, legal, or policy concerns with a proposed resource development project.

The framing of participatory rights as a question of standing arguably encourages this sort of challenges. It places the obligation on the prospective participant to demonstrate he or she has "standing" to participate in the decision-making process and invites contending arguments from the project proponent and other parties. Lost in this characterization is the question of whether a decision-maker responsible for furthering the public interest in resource development has the obligation to hear public input and give interested citizens a meaningful opportunity to influence the exercise of state power.

The public interest character of resource development is undeniable and expressly recognized in applicable legislation. The NRCB Act, for example, obligates the NRCB to consider the public interest in its decisions. Similarly, the EPEA and the Water Act include public input in resources and environmental decision-making as one of their underlying purposes. It is difficult to comprehend how resource project decision-makers in Alberta comply with this direction from the legislature when they refuse to hear public input beyond that from those personally affected in close vicinity to a project. This concern is magnified in relation to the EAB given its function as an appellant body that hears appeals under the EPEA and the Water Act concerning the legality of project decisions made by ESRD.

\section{The Right to Public Participation}

Each of the decision-makers responsible for approving resource projects is a creature of statute or exercises its power over resource projects under statutory direction. They do not have inherent authority to determine who has a right to participate before them or, to put it another way, who they are obligated to hear. The final word on the obligation of these decision-makers to hear public input rests with the judiciary. Alberta courts have been provided with the opportunity to consider this issue on many occasions, particularly in recent years as the number of persons excluded from participating in resource development project decision-making has increased.

We might expect Alberta courts would have provided some assessment on the value of public participation in resources and environmental decision-making, taking into consideration the overall socio-political context of resource development in Alberta today, the governing legal framework, the public interest character of these decisions, and the role of public participation in administering the rule of law. We might expect Alberta courts to have noted the emergence of international law endorsing the right to public participation in resources and environmental decision-making. And we might expect Alberta courts to have questioned how a statutory decision-maker satisfies its obligation to give consideration to the 
public interest in its decisions when that decision-maker narrowly interprets its obligation to hear the public and outright refuses to hear general public concerns in some instances.

Before examining the jurisprudence in detail to explore whether Alberta courts have met any of these expectations, it is necessary to say a few words about how the issue gets before the courts. Because participation in resources and environmental decision-making in Alberta is governed by statute, administered by decision-makers acting under statutory powers, and the legal framework channels public input into project reviews, the issue of public participation comes before the courts in the context of judicial review or statutory appeal concerning a project review decision made by an administrative decision-maker such as those examined in Part III. For example, REDA and the NRCB Act provide that decisions by the AER or the NRCB may be appealed to the Alberta Court of Appeal with leave of the Court. ${ }^{115}$ Of note, there has not been a Court of Appeal decision concerning an NRCB ruling on participatory rights. ${ }^{116}$ Where the governing legislation is silent on an appeal to the courts, the matter proceeds as a judicial review. This is how EAB decisions get before the Alberta Court of Queen's Bench.

The question of public participation in resources and environmental decision-making came before Alberta courts for the first time in relation to a controversial pulp mill located near the City of Athabasca in north-central Alberta. Alberta-Pacific Forest Industries (Alpac) applied to construct a new pulp mill near Athabasca, and in 1989 Alberta appointed an ad hoc review panel to assess the socio-ecological impacts of the proposed mill. The panel heard submissions from approximately 750 persons in hearings conducted in various locations within Alberta and the Northwest Territories. In March 1990 the panel recommended that construction of the mill be delayed to allow for further studies on its environmental impact, but the Alberta government approved construction without delay in late $1990 .^{117}$

A number of environmental groups organized to oppose the construction of the Alpac mill, and subsequent to the mill approval they opposed construction of the associated waste landfill. Construction of the landfill was not reviewed by the earlier environmental impact assessment, and it was instead subject to its own review by the Athabasca Health Unit under the Public Health Act. ${ }^{118}$ The Unit approved the landfill without giving reasons in July 1993 after considering submissions from Alpac and those opposed to the facility. Some of the persons who appeared before the Unit, including the Friends of the Athabasca Environmental Association, sought to appeal the approval before the Public Health Appeal Board pursuant to the Public Health Act. At the Board, counsel for Alpac argued Friends of the Athabasca Environmental Association and several other applicants who did not live in the vicinity of the landfill, had no standing to initiate an appeal on the grounds that they were not "directly affected” by the landfill approval. The Board accepted this argument and denied standing to

$115 \quad$ REDA, supra note 39, s 45; NRCB Act, supra note 43, s 31.

116 The Court of Appeal has denied leave to appeal on two occasions where the applicant sought to appeal an NRCB decision on funding for participation. See Hazardous Waste Importation Review Coalition v Alberta (Natural Resources Conservation Board), 1994 ABCA 184, 19 Alta LR (3d) 302; Indian Assn (Alberta) v Alberta (Natural Resources Conservation Board), 1995 ABCA 315, 33 Alta LR (3d) 396. Mary Richardson, Joan Sherman \& Michael Gismondi, Winning Back the Words: Confronting Experts in an Environmental Public Hearing (Toronto: Garamond Press, 1993) at 3-5. See also Richardson, Sherman \& Gismondi, supra note 3. 
the Association by relying on a provision in the Public Health Act which stated a person who is directly affected by a decision of the Unit may appeal that decision to the Board.

Friends of the Athabasca Environmental Association sought judicial review of the Board's decision. In April 1994 Justice Veit of the Court of Queen's Bench ruled the Board was correct in its interpretation that the phrase "directly affected" in the Public Health Act, and in particular that the word "directly," brings a restrictive connotation to those persons who may appear before the Board. ${ }^{119}$ Justice Veit thus denied the judicial review application, and in doing so noted a similar finding in an unreported ruling by Justice Agrios in parallel proceedings at the Court concerning another waste management facility. ${ }^{120}$

The Alberta Court of Appeal upheld the decisions of both Justices Veit and Agrios in separate proceedings heard by the same panel. In Friends of the Athabasca Environmental Association v. Alberta Public Health Advisory and Appeal Board ${ }^{121}$ the Court of Appeal made a number of important rulings. The Court noted that while the Board is required to take public interest considerations into account concerning a public health matter that may transcend the interests of the parties before it, that does not necessarily mean the all members of the public have the right to participate in front of the Board. ${ }^{122}$ Moreover, in any event the parties with standing before the Board were entitled to raise public interest concerns. ${ }^{123}$ The Court also reaffirmed the interpretation of “directly affected” given by Justice Veit:

The mandate of an administrative tribunal and its legal process must be construed in accordance with the legislative intent. In our view, that intent is clear. The use of the modifier "directly” with the word "affected" indicates an intent on the part of the Legislature to distinguish between persons directly affected and indirectly affected. An interpretation that would include any person who has a genuine interest would render the word "directly" meaningless, thus violating fundamental principles of statutory interpretation. ${ }^{124}$

In the parallel decision of Canadian Union of Public Employees, Local $30 \mathrm{v}$. WMI Waste Management of Canada Inc., ${ }^{125}$ the same panel of the Court observed this restricted interpretation of "directly affected" as consistent with the interpretation given to the phrase by the UK Privy Council in $1898 .^{126}$

These four judgments concerning participation in decisions made under the Public Health Act represent a defining moment for public participation in resources and environmental decision-making in Alberta. Looking back now, the Alpac mill controversy appears as the beginning of sustained arguments by project applicants against public participation in project approvals. The judgments were followed in the 1996 Kostuch v. Environmental Appeal Board (Alta) decision by the Court of Queen's Bench which applied the same restrictive interpretation to "directly affected" in the EPEA to uphold the EAB decision to deny the late

Friends of the Athabasca Environmental Association v Alberta Public Health Advisory and Appeal Board (1994), 153 AR 225 (QB) at para 33.

Ibid at para 13 .

(1996), 181 AR 81 (CA).

Ibid at para 7.

Ibid at para 9 .

Ibid at para 10 [citation omitted].

(1996), 178 AR 297 (CA).

Ibid at para 18. 
Martha Kostuch the right to participate. ${ }^{127}$ This judgment has subsequently been cited by the EAB in numerous decisions as authority for the view that a person seeking to argue an appeal before it must demonstrate the decision in question affects them in a personal manner that is distinct from an effect on the public at large. ${ }^{128}$ Also of note, the Queen's Bench Kostuch judgment and the two Court of Appeal judgments under the Public Health Act were cited by the ERCB in 2007 as authority for excluding the participation of a member of the public concerning an application by Shell Canada to drill a gas well on public lands. ${ }^{129}$

EAB standing determinations also commonly cite several paragraphs from Justice MacIntyre's 2003 decision in Court v. Environmental Appeal Board (Alta). ${ }^{130}$ In the Court decision, Justice MacIntyre reviews EAB standing decisions and from that review elicits the following five principles on standing at the EAB: (1) the issue of standing is a preliminary matter to be decided before the merits; (2) the person who seeks standing at the EAB must demonstrate on the balance of probabilities that he or she will be directly affected by the decision in question; (3) the person need not demonstrate the effects are unique or different from other Albertans; (4) the person must demonstrate the project will harm a natural resource the person uses or will harm the person's use of that resource; (5) the person must demonstrate the potential for harm, but not actual harm. ${ }^{131}$

There are, as of yet, no judicial decisions concerning the AER hearing provisions contained in sections 32 thru 34 of REDA and the "directly and adversely affected" phrase contained therein, but there are a number of Court of Appeal decisions considering the “directly and adversely affected" phrase set out in section 26(2) of the now-repealed Energy Resources Conservation Act as it applied to the ERCB. The leading interpretation of section 26(2) in the Energy Resources Conservation Act was provided by the Court of Appeal in its 2005 Dene Tha' First Nation v. Energy \& Utilities Board (Alta) decision. ${ }^{132}$ The applicant energy company proposed to drill wells on Crown lands that were located outside the Dene Tha' First Nation reserve. The Dene Tha' requested an ERCB hearing to oppose the wells, and the Board rejected the request on the basis that the Dene Tha' did not have standing. At the Court of Appeal, Justice Côté endorsed the following interpretation of section 26(2) provided by the ERCB:

(1996), 182 AR 384 (QB) at paras 13-23. Bankes, supra note 44 provides some analysis of this Queen's Bench Kostuch decision. The underlying EAB decision is described briefly in Part III (supra note 55 and accompanying text).

For a recent example of this reasoning by the EAB see Re Waste Management of Canada Corp, [2012] AEABD No $15(\mathrm{QL})$ at para 89.

Prehearing Meeting Applications for a Well and Associated Pipeline Licences - Shell Canada Waterton Field, supra note 92 at 5. 2003 ABQB 456, 333 AR 308 [Court].

Ibid at paras 67-72. Bankes, supra note 44 provides some analysis of the Court decision.

2005 ABCA 68, 363 AR 234 [Dene Tha']. It is noteworthy that section 26(2) was enacted in 1969, but judicial consideration of the provision did not occur until 2005. After 2005 the Court of Appeal faced many leave to appeal requests concerning participatory rights before the ERCB. The Court has denied leave to appeal in the majority of cases. Leave applications on participatory rights which have been denied by the Court include Stiles Estate v Alberta (Energy \& Utilities Board), 2005 ABCA 308, 53 Alta LR (4th) 235; Bartlett $v$ Energy \& Utilities Board (Alta), 2005 ABCA 340, 376 AR 192; Sawyer $v$ Energy and Utilities Board (Alta), 2007 ABCA 297, 422 AR 107 [Sawyer]; Prince v Alberta (Energy Resources Conservation Board), 2010 ABCA 214, [2010] 4 CNLR 184; SemCAMS ULC v Alberta (Energy Resources Conservation Board), 2010 ABCA 397, [2010] AJ No 1447 (QL) [SemCAMS ULC]; Visscher v Alberta (Energy Resources Conservation Board), 2011 ABCA 209, [2011] AJ No 737 (QL). 
The Board correctly stated here that that provision in s. 26(2) has two branches. First is a legal test, and second is a factual one. The legal test asks whether the claim right or interest being asserted by the person is one known to the law. The second branch asks whether the Board has information which shows that the application before the Board may directly and adversely affect those interests or rights. The second test is factual. $^{133}$

Justice Côté ruled the Dene Tha’ met the first branch of the test by asserting the potential adverse affect of the wells on a constitutional Aboriginal right, and that the ERCB correctly acknowledged such right as meeting the first branch. ${ }^{134}$ However, he refused to set aside the Board's finding that the Dene Tha' provided no facts upon which the Board could assess whether a right may be adversely affected by the wells (the second branch of the section 26(2) test). ${ }^{135}$ Justice Côté stated it is reasonable for the ERCB to require the person to submit evidence to demonstrate some degree of proximity between the proposed project and the adverse effect. ${ }^{136}$

In January 2009 the Court heard an application by two energy companies for an order to overturn an ERCB section 26(2) decision that denied them a hearing to oppose a facility licence amendment. ${ }^{137}$ ATCO Midstream and Nova Chemicals sought a hearing in front of the Board to object to the application by Keyera Energy for approval to extract saleable ethane from natural gas flowing into its gas processing facility. Both ATCO and Nova objected to the Keyera application, in part, because of potential adverse economic impacts. ATCO asserted the upstream ethane extraction would have a negative effect on its own extraction facilities, and Nova asserted the upstream ethane extraction would reduce downstream supply and raise the marginal cost of ethane it purchases. The Court agreed with the ERCB interpretation that an adverse impact to an economic interest alone did not engage the right to participate before the ERCB under section 26(2). ${ }^{138}$

The Court next confronted participatory rights at the ERCB in its 2009 Kelly v. Energy Resources Conservation Board (Alta) decision. ${ }^{139}$ In January 2009 the ERCB denied a hearing to Susan Kelly, Linda McGinn, and Lillian Duperron in relation to an application by Grizzly Resources to drill two sour gas wells near their residences. All three lived outside the ERCB's prescribed face-to-face consultation radius surrounding the proposed gas wells, but were within a wider zone known as the protective action zone that anticipates the movement of a sour gas plume upon release from the well. The ERCB had denied them participatory rights on the basis they resided outside the ERCB consultation radius and did not establish to the Board's satisfaction that they would be affected in a different way or greater degree than the public generally. The Court of Appeal set aside the ERCB decision, ruling that the phrase "directly and adversely affected" does not require a person to establish they may be affected in a different way or to a greater degree than the public generally. ${ }^{140}$

\footnotetext{
133 Dene Tha', ibid at para 10.

134 Ibid at paras 11-12.

135 Ibid at paras 13-15.

$136 \quad$ Ibid at para 14.

137 ATCO Midstream Ltd v Energy Resources Conservation Board (Alta), 2009 ABCA 41, 446 AR 326.

$138 \quad$ Ibid at paras 9-11. See also SemCAMS ULC, supra note 132 at para 15.

1392009 ABCA 349, 464 AR 315 [Kelly \#1].

$140 \quad$ Ibid at paras 30-32.
} 
Kelly and Duperron were at the Court of Appeal again in late 2011 after being denied another hearing by the ERCB in relation to sour gas wells proposed for a location approximately six kilometres from their residence. In this case the ERCB had denied them participatory rights on the grounds they failed to establish sufficient proximity between their residence and the sour gas wells and the ERCB also rejected the argument that the prospect of having to be evacuated in the case of a sour gas release was an adverse effect. In 2011, the Court ruled the Board's interpretation of "directly and adversely affected” in this case was unreasonable and ordered the ERCB to reconsider its decision to deny Kelly and Duperron participatory rights. ${ }^{141}$ The Court confirmed that proximity between an energy project and the person seeking standing before the ERCB is a legitimate consideration in determining whether a person may be "directly and adversely affected." ${ }^{142}$ The Court also reiterated its finding from Kelly \#1 that a person does not have to demonstrate they may be affected to a greater degree than the public in general. ${ }^{143}$ The Court also stated the adverse effect must be of some magnitude, but that the risk need not be a certainty or even likely to occur. ${ }^{144}$ And finally, the Court reflected on the overall purpose underlying section 26(2) stating

[t]he right to intervene in the Act is designed to allow those with legitimate concerns to have input into the licensing of oil and gas wells that will have a recognizable impact on their rights, while screening out those who have only a generic interest in resource development (but no "right" that is engaged), and true "busybodies.",145

In January 2012, Kelly and others were again before the Court of Appeal, this time to appeal a decision by the ERCB to deny them a costs award. The issue here did not concern the bare right to participate, but rather concerned the interpretation of section 28 of the Energy Resources Conservation Act which provided the ERCB with authority to award monetary compensation to hearing participants to offset their expenses incurred to participate in an energy project hearing. The ERCB had denied their request for a cost award on the basis of its interpretation that section 28 only provides the Board with authority to grant costs to a hearing participant where there is evidence to demonstrate an energy project may have a direct and adverse impact on that person's land. In 2012, the Court of Appeal ordered the ERCB to reconsider its costs decision and ruled the eligibility for a costs award under section 28 of the Energy Resources Conservation Act included those hearing participants who demonstrate a potential adverse impact on their use or occupancy of land, and not just those who can demonstrate adverse impacts to the land itself. ${ }^{146}$

The subsequent repeal of the Energy Resources Conservation Act renders the Court's statutory interpretation in Kelly \#3 somewhat moot, since there is no equivalent provision in $R E D A$. However, the judgment is still noteworthy for the strong statement by the Court of Appeal about the role and accessibility of project review hearings towards ensuring the legitimacy of resource development in Alberta:

2011 ABCA 325, 515 AR 201 [Kelly \#2].

Ibid at para 21.

Ibid at para 22.

Ibid at para 26.

Ibid.

2012 ABCA 19, 519 AR 284 [Kelly \#3]. 
In today's Alberta it is accepted that citizens have a right to provide input on public decisions that will affect their rights.

In the process of development, the Board is, in part, involved in balancing the interest of the province as a whole, the resource companies, and the neighbours who are adversely affected.... Granting standing and holding hearings is an important part of the process that leads to development of Alberta's resources. The openness, inclusiveness, accessibility, and effectiveness of the hearing process is an end unto itself. Realistically speaking, the cost of intervening in regulatory hearings is a strain on the resources of most ordinary Albertans, and an award of costs may well be a practical necessity if the Board is to discharge its mandate of providing a forum in which people can be heard. In other words, the Board may well be "thwarted" in discharging its mandate if the policy on costs is applied too restrictively. It is not unreasonable that the costs of intervention be borne by the resource companies who will reap the rewards of resource development. ${ }^{147}$

A number of observations can be taken from this examination. Generally speaking, judicial consideration of the right to participate in resources and environmental decisionmaking in Alberta consists almost entirely of literal statutory interpretation and judicial deference to administrative decisions. The Friends of the Athabasca Environmental Association decisions issued in the 1990s restrict the right to participate on the basis of meaning attributed to the word "directly" in applicable legislation. ${ }^{148}$ The 1996 Kostuch, ${ }^{149}$ 2003 Court, ${ }^{150}$ and 2005 Dene Tha ${ }^{151}$ decisions all defer to the narrow interpretations given to "directly affected" and "directly and adversely affected" by the EAB and the ERCB, respectively. In both the 2009 Kelly \#1 and 2011 Kelly \#2 decisions ${ }^{152}$ the Court of Appeal takes some issue with how the ERCB applied the "directly and adversely affected” test, but the Court does not question the Board's overall view that it is only required to hear those persons who can demonstrate its decision may have a direct, personal impact on them.

The strong remarks by the Court of Appeal in its 2012 Kelly \#3 decision ${ }^{153}$ on the role of hearings in context of resource development suggest perhaps the Court is moving away from the formalism and deference exhibited in the earlier jurisprudence. The Court is not deciphering statutory text or deferring to the ERCB when it describes the hearing process as an "end unto itself." 154 The words chosen by the Court to describe the hearing process for an energy project review suggest some appreciation for the overall socio-political context of resource development in Alberta today and the importance of opportunities for citizens to influence the exercise of state power. But the Court offers little in terms of what "openness" or "inclusiveness" means for the hearing process in an energy project review, ${ }^{155}$ and does not move away from its earlier rulings that participatory rights are only held by those persons who can demonstrate an energy project may affect them personally.

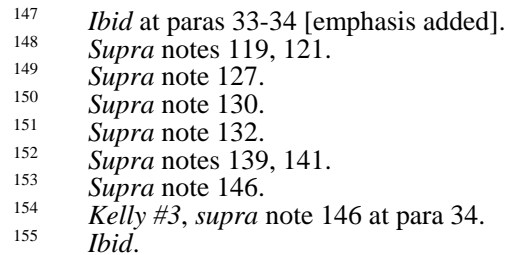


The public interest character of resources and environmental project decisions continues to have no identifiable impact on the consideration of participatory rights by Alberta courts. In its 1996 Friends of the Athabasca Environmental Association decision the Court of Appeal remarkably held that public interest decision-making does not necessarily require public input because participants with private interests at stake can also raise general public concerns in the hearing process. ${ }^{156}$ The Court of Appeal denied leave in a 2007 case wherein the obligation of the ERCB to hear public concerns in an energy project review had become a clear point of contention on energy projects located on public lands. ${ }^{157}$ The Court of Appeal is again somewhat dismissive of public participation in its 2011 Kelly \#2 judgment, ruling that participatory rights should not be held by those with merely a "generic interest" in resource development. ${ }^{158}$

\section{CONCLUSION}

An initial glance at governing legislation and regulatory policy would suggest public participation is considered an essential component of resources and environmental project decision-making in Alberta. In one form or another, the various statutes reference the need for public input in resource decisions that affect the environment and for project decisionmakers to ensure approvals are in the public interest having regard for the economic, social, and environmental effects of the proposed resource development. Regulatory directives and guidelines issued by resource project decision-makers encourage project proponents to engage with the public as part of their application for project approval. It seems anyone with an interest is welcome to participate in resources and environmental project decision-making. A closer look reveals a very different reality.

The review of resource project decisions conducted here suggests public participation was in fact considered an essential component of resources and environmental project decisionmaking in Alberta until sometime in the early to mid-1990s. After this time, resource project decision-makers began to restrict participatory rights to those persons who could demonstrate they may be personally affected by a project under review. Stricter views from decisionmakers on the entitlement to participate have given rise to the issue of a right to participate in resources and environmental decision-making. Given the public interest character of resource development, the fundamental issue that has been explored here is whether these decision-makers are obligated to hear from the public in the course of approving resource development projects.

The only reasonable conclusion from the analysis in this article is that there is currently no legal right to public participation in resources and environmental project decision-making in Alberta. Project decision-makers have no obligation to hear organized public interest groups or members of the public at large who are unable to demonstrate how a project may personally affect them. Submissions which only set out general legal or policy concerns with a resource development project are often dismissed. Government officials have even opposed public participation in resource project decision-making, sometimes on questionable grounds. 
The public interest character of resource development decisions has thus far had no identifiable impact on the consideration of participatory rights by Alberta courts. The jurisprudence on point is a collection of decisions consisting largely of judicial deference to the statutory interpretation provided by resource project decision-makers on their obligation to hear from a very narrow selection of persons and their view that participation in a resource project decision is nothing more than a means to safeguard private interests. Resources and environmental project decision-making is thus not necessarily subject to public scrutiny and it becomes more difficult to hold officials exercising public power over resource development legally accountable for their actions. The role of public participation as an accepted means to influence the exercise of state power over matters concerning the public interest deserves more critical and focused attention from Alberta courts. 